\title{
Gestão social e cidadania deliberativa: uma análise da experiência dos Coredes no Rio Grande do Sul, 1990- 2010
}

\author{
Social management and deliberative citizenship: an analysis of the Coredes experience in \\ Rio Grande do Sul, 1990-2010
}

\author{
Sérgio Luís Allebrandt ${ }^{1}$ \\ Dieter Rugard Siedenberg ${ }^{2}$ \\ Jorge Oneide Sausen ${ }^{3}$ \\ Cristiele Tomm Deckert ${ }^{4}$
}

\begin{abstract}
Resumo
Este artigo aborda a prática da gestão social nos Conselhos Regionais de Desenvolvimento (Coredes), experiência vivenciada no Rio Grande do Sul ao longo dos últimos vinte anos. A gestão social, conforme aqui entendida, requer a participação da sociedade civil na gestão pública e do desenvolvimento. O estudo utiliza a abordagem interpretativa inserida no paradigma da teoria social crítica, estabelecendo uma matriz de categorias e subcategorias de análise que contempla os princípios da inclusão, do pluralismo, da igualdade participativa, da autonomia e do bem comum, presentes no conceito de cidadania deliberativa. Os Coredes, sendo arranjos institucionais que atuam na promoção do desenvolvimento, constituem-se em espaços públicos potenciais para a prática da cidadania deliberativa. Se as experiências participativas já são significativas em âmbito local, como no caso dos conselhos municipais e do orçamento participativo, ainda são raras em âmbito regional e estadual, daí a importância dos Coredes, ativos após seis governos estaduais. Portanto, os Coredes são processos e espaços de cidadania deliberativa que produzem mudanças, ainda que lentamente, na perspectiva pública dos indivíduos, na cultura da sociedade civil, no perfil da sociedade política e no modus operandi do aparelho burocrático e dos governos. Por outro lado, trata-se de processo dialógico que necessita ser construído e reconstruído permanentemente pelos participantes, para evitar o risco do controle corporativo, político ou administrativo por meio de cooptação e manipulação, ainda presente nas incipientes experiências de gestão social.
\end{abstract}

Palavras-chave: Gestão social. Cidadania deliberativa. Participação social. Conselhos regionais de desenvolvimento.

Artigo submetido em 20 de março de 2011 e aceito para publicação em 04 de agosto de 2011.

1 Doutor em Desenvolvimento Regional pelo PPGDR/Unisc; Professor Titular da Unijuí (Mestrado em Desenvolvimento). Endereço: DACEC/Unijuí, Rua do Comércio, 3000, Bairro Universitário, Caixa Postal 590, CEP 98700-000, ljuí - RS, Brasil. E-mail: allebr@unijui.edu.br

2 Doutor em Geografia pela Universität Tübingen (Eberhard-Karls) Alemanha; Professor da Unijuí (Mestrado em Desenvolvimento). Endereço: DACEC/Unijuí, Rua do Comércio, 3000, Bairro Universitário, Caixa Postal 590, CEP 98700-000, ljuí - RS, Brasil. E-mail: dieterrs@unijui.edu.br

${ }^{3}$ Doutor em Engenharia da Produção pela UFSC; Professor da Unijuí (Mestrado em Desenvolvimento). Endereço: DACEC/Unijuí, Rua do Comércio, 3000, Bairro Universitário, Caixa Postal 590, CEP 98700-000, ljuí - RS, Brasil. E-mail: josausen@unijui.edu.br

${ }^{4}$ Mestranda em Desenvolvimento no PPGD/Unijuí; Bolsista Capes ProAdm; Bacharel em Comunicação Social pela Unicruz. Endereço: Rua Osvaldo Rick, 92, Bairro Morada do Sol, CEP 98700-000, ljuí - RS, Brasil. E-mail: cristieledeckert@hotmail.com 


\begin{abstract}
This article discusses the practice of social management in Regional Development Councils (Coredes) experienced in Rio Grande do Sul over the past twenty years. Social management, as understood here, requires the participation of civil society in public administration and development. The study uses the interpretative approach embedded in the paradigm of critical social theory, establishing a matrix of categories and subcategories of analysis that include the principles of inclusion, pluralism, equal participation, autonomy and the common good found in the concept of deliberative citizenship. The Coredes as institutional arrangements that work to promote development are potential public spaces for the practice of deliberative citizenship. If the participatory experiences are already significant locally, as in the case of municipal councils and participatory budgeting, they remain rare at the regional and state levels, this highlights the the importance of Coredes, still active after six state government mandates. Therefore, Coredes are processes and spaces for deliberative citizenship, which produce changes, albeit slowly, in the public perspective of individuals, in the culture of civil society, in the profile of the political society and in the modus operandi of bureaucracy and governments. Moreover, it is the dialogic process that needs to be continuously constructed and reconstructed by the participants to avoid the risk of corporate, political or administrative control through cooptation and manipulation, even in these incipient social management experiences.
\end{abstract}

Keywords: Social management. Deliberative citizenship. Social participation. Regional development councils.

\title{
Introdução
}

Este artigo tem como tema a gestão social praticada nos Conselhos Regionais de Desenvolvimento (Coredes) do Rio Grande do Sul, espaços públicos institucionalizados de participação social na gestão pública e na gestão do desenvolvimento. A participação da sociedade civil é ainda recente no Brasil, onde a democracia está em construção há não mais de duas décadas, após outras duas décadas de vigência de ditadura militar que sufocou as tênues experiências de envolvimento da sociedade no processo de construção de políticas sociais de base no início da década de sessenta do século passado.

O processo de redemocratização do Brasil caracterizou-se, no plano político, não apenas pela consolidação do sistema democrático-representativo, mas também pela institucionalização de um conjunto de instrumentos legais incorporados na Constituição Federal de 1988, nas Constituições Estaduais e nas Leis Orgânicas Municipais, possibilitando a instituição de dinâmicas, arranjos e mecanismos participativos na gestão das políticas públicas, viabilizando a construção de um sistema democrático-participativo, ou seja, a instituição da democracia semidireta.

Por isso, fruto, em grande parte, do envolvimento da sociedade na construção desta democracia, o país vivencia, neste período, uma verdadeira reinvenção de governança e governabilidade, especialmente por meio do estabelecimento de novas formas de relacionamento entre a sociedade civil, o estado e o mercado, com ênfase em novas dinâmicas de participação como processo de ação coletiva.

Estas novas dinâmicas são resultado de complexos processos de construção social de que participam os indivíduos/cidadãos, os grupos e as organizações, num sistema de relações de poder e de institucionalidade em espaços públicos de interação com o Estado. Há um consenso geral entre estudiosos do poder local (AVRITZER, 1999; COHN, 1998; DOWBOR, 1994, 1995, 1999; FEDOZZI, 1999, 2000; FISCHER, 1996, 2002) de que, no Brasil, seguindo uma tendência mundial de valorização dos espaços subnacionais, com a Constituição de 1988, ganha impulso um processo de descentralização, com um conjunto importante de tarefas, antes assumidas pelo poder central, passando ao âmbito dos governos subnacionais, especialmente os municípios. 
Seja em decorrência das reformas estruturais do setor público no mundo nas décadas de 1970 e 1980 e, no Brasil, em especial na de 1990, com a eliminação gradativa do estado do bem-estar social ${ }^{5}$ (welfare state), dando lugar ao estado neoliberal, ou em decorrência do debate em torno do (re)fortalecimento do papel do Estado na última década no Brasil e no mundo (em especial a partir da crise financeira de 2008), as instâncias locais e regionais passam a assumir papel importante na condução das políticas públicas. O município assume, então, cada vez mais o papel de welfare não só pelo aumento dos gastos nas áreas da saúde, educação e promoção social, na condição de executor das políticas sociais antes a cargo da União, mas também pelas políticas voltadas à geração de emprego e renda e de incentivo ao desenvolvimento local. Passa, deste modo, à condição de promotor do desenvolvimento socioeconômico com base em ações de âmbito local. ${ }^{6}$

Estas mudanças exigiram modificações na forma tradicional de formular e implementar as políticas. O processo de democratização por que passou o país, a gradativa incorporação da cidadania como elemento irreversível dos espaços locais, ao mesmo tempo que o processo de globalização aumentava os contingentes de excluídos, exigiram a incorporação efetiva da sociedade civil organizada como sujeito importante no processo de formação e gestão das políticas públicas. É nos municípios, especialmente nos de pequeno e médio porte, ${ }^{7}$ onde os cidadãos estão mais próximos dos governantes responsáveis pelas políticas públicas, que as exigências pelo atendimento das demandas passam a ser cada vez mais cobradas. Por isso, foi neste âmbito local que surgiram alternativas de gestão descentralizada e de solução aos problemas das comunidades e dos cidadãos, que, em muitos casos, serviram de exemplo a políticas públicas de âmbito regional ou mesmo nacional. Mas também a indução de ações, valendo-se de políticas nacionais e regionais, acaba se concretizando na esfera territorial local em razão da necessária integração entre as diferentes escalas territoriais.

Assim, seja pela necessidade sentida no processo de construção dessa nova dinâmica do desenvolvimento socioeconômico ou pela indução de políticas de nível macro, experiências de articulações e de ações de âmbito supramunicipal vieram a ser exigidas e praticadas cada vez mais. Considerando que a estrutura federativa brasileira não contempla a instância político-administrativa intermediária entre o Estado e o município, diferentes experiências surgiram nos estados brasileiros, visando à institucionalização de espaços de discussão e construção de políticas de desenvolvimento local e regional.

Como afirma Veiga (2006, p. 19-20),

[...] os diversos tipos de arranjos institucionais de caráter inframunicipal, municipal ou intermunicipal; micro ou mesorregional; e até estadual ou interestadual, podem ser vistos como decorrências inevitáveis da óbvia incapacidade de uma simples estrutura do tipo União/Estados/Municípios democratizar uma sociedade que objetivamente se organiza em uma dúzia de imensas cidades metropolitanas, rodeadas por 160 microrregiões polarizadas

${ }^{5}$ Como bem lembra Fischer (2002), o Estado brasileiro em nenhum momento histórico configurou-se como o modelo de welfare state, visto que jamais foi implantado em sua plenitude no Brasil.

6 É preciso deixar claro que este papel da esfera local não elimina a importância do papel do Estado nacional na discussão e proposição de políticas de desenvolvimento macrorregional; é importante ressaltar, neste sentido, uma retomada do planejamento governamental como instrumento de gestão do desenvolvimento socioeconômico e da integração nacional; o que é preciso ter em mente é que estes processos de nível macro devem estar em sintonia com os processos de desenvolvimento local e regional.

7 De acordo com os dados do Censo 2010 do IBGE, dos 5.565 municípios brasileiros existentes em 2010, 70\% possuem menos de vinte mil habitantes e $45 \%$, menos de dez mil habitantes. A grande maioria destes municípios são essencialmente rurais e interioranos. 
e dominadas por aglomerações urbanas ou cidades, e por uma imensa variedade de situações que ocorrem em 390 microrregiões rurais.

É desta lógica que diferentes processos sociopolíticos dão origem, durante a década de noventa, aos Conselhos Regionais de Desenvolvimento (Coredes) no Rio Grande do Sul, aos Fóruns de Desenvolvimento Regional (FDRs) em Santa Catarina e aos Conselhos Regionais de Desenvolvimento Sustentável (CRDS) no Ceará. ${ }^{8}$

Estas dinâmicas permitiram maior autonomia aos municípios, com a ruptura do desenho tradicional das políticas públicas, com a implementação de políticas sociais de base em virtude das quais as comunidades locais se mobilizaram para atuar como parceiros de mecanismos de gestão democrática e participativa no âmbito local, em torno da discussão pública de questões específicas. O município e as regiões supramunicipais $^{9}$ parecem constituir-se, assim, em espaço privilegiado para a concretização da democracia, com a participação cidadã da sociedade, com ênfase nas características de territorialidade, de partilha de poder e de deliberação em espaços públicos. No entanto, esta parece ser uma concepção ideal distante da prática generalizada, que utiliza o discurso da participação muito mais como fonte legitimadora do poder político local, ou porque os mecanismos de participação, como os conselhos municipais e regionais, constituem-se apenas formalmente para atender exigências legais de repasse de recursos no processo de descentralização. É, também, por isso que os municípios sofrem críticas, de toda ordem, por irresponsabilidade fiscal e pela ineficiência e ineficácia de suas administrações.

Este estudo desenvolveu-se tendo por foco a relação aparentemente dicotômica dos aspectos positivos e negativos das experiências e práticas de gestão social destes arranjos de escala local e regional; especialmente quanto à organização social coletiva do processo, às relações interinstitucionais e à participação da sociedade civil no processo. O objetivo central foi analisar entendimentos, intencionalidades e formas de agir praticadas pelos Coredes na gestão do processo de desenvolvimento local e regional e no fortalecimento da cidadania. A pesquisa buscou identificar o conteúdo, as formas e o significado de participação cidadã nas decisões do poder público, baseando-se no estudo da organização e do funcionamento dos Coredes e das práticas e representações de alguns dos principais sujeitos envolvidos no processo de gestão do desenvolvimento local e regional à luz de uma matriz de categorias e subcategorias.

O estudo justifica-se pela expressão política e social que tais formas de organização oportunizaram no processo de emergência da cidadania, na consolidação da participação de diferentes sujeitos sociais, na construção de discursos entre sociedade civil, mercado e Estado e na prática da gestão social destes arranjos institucionais que se organizam e atuam em rede. Os Coredes interagem com o Estado em suas múltiplas esferas, aqui em especial as de âmbito municipal e estadual, mas também na interface dos poderes executivo e legislativo, contribuindo para mudanças nas relações dessas instâncias. Um dos desafios da análise da democracia hoje no Brasil é tentar entender melhor as mediações entre o Estado e a sociedade civil e, para

8 Bandeira (2000), em estudo que apresenta reflexões sobre a incorporação de práticas participativas e mecanismos voltados para a articulação de atores sociais às ações relacionadas com a promoção do desenvolvimento regional, analisa diferentes experiências de construção de instituições participativas em escala regional no Brasil. Siedenberg (2000) analisa experiências de desenvolvimento regional endógeno e Birkner (2006), experiências de arranjos institucionais com foco na descentralização políticoadministrativa.

${ }^{9}$ Por regiões supramunicipais entende-se qualquer recorte territorial que reúna pelo menos dois municípios que se organizem com algum tipo de arranjo institucional com o objetivo de executar políticas públicas e enfrentar problemas de difícil solução de forma isolada. É o caso dos consórcios públicos intermunicipais, associações de municípios, Coredes, conselhos regionais de saúde e educação, entre outros. 
tanto, é necessário compreender os diversos arranjos e formas de participação institucionalizada que surgiram e vêm se consolidando desde os anos noventa do século passado.

A produção de conhecimentos teórico-empíricos que analisam os processos de organização e gestão do desenvolvimento local e regional e os mecanismos de responsabilização e eficácia social, de governança e governabilidade presentes nesses processos contribuem para a construção da cidadania e da democracia, ainda tão incipiente no Brasil. Tais estudos, ainda que significativos no âmbito dos governos locais e das experiências de concertação local e regional, são ainda insuficientes se for considerada a diversidade política, social, econômica e cultural do Brasil, o que ocasiona grandes diferenças entre os municípios e regiões.

No que se refere ao Rio Grande do Sul, em especial às experiências de governança do desenvolvimento regional nas últimas décadas, de acordo com Veiga (2006, p. 21),

[...] são raros (e certamente pouco lidos) os estudos que se propuseram a reconstruir a trajetória histórica dessas [...] visões públicas do desenvolvimento territorial. Por outro lado, há um rico conhecimento tácito disperso entre protagonistas e observadores dessa experiência, mas não se pode dizer que ele esteja sistematizado (e, menos ainda, que tenha sido assimilado por significativo número de quadros governamentais, políticos, acadêmicos, sindicais, etc., que hoje estão envolvidos em ações de desenvolvimento).

\section{Apontamentos Metodológicos}

Na perspectiva filosófica que orienta a posição teórica deste estudo, a escolha da metodologia evidencia as opções teóricas e as intencionalidades dos pesquisadores. Portanto este estudo aconteceu permeado pela intersubjetividade e interdiscursividade, que é o lugar do diálogo e da visão plural. Estes processos interativos pressupõem movimento dialógico e, desta forma, possibilitam compreender a dinamicidade da vida e do conhecimento que é gestado dinamicamente na trama social e interdiscursiva, evidenciando-se manifestos mediante discursos (documentos legais, debates, entrevistas, questionários, cartas, depoimentos) da observação participante, da experiência pessoal e, também, de práticas sociais em diversas instâncias.

As práticas sociais das quais se fez a interpretação estão inseridas em contextos e processos históricos específicos, constituem-se produções discursivas e têm gerado avanços e mudanças significativas (embora ainda insuficientes, porque as relações de poder são assimétricas) nas políticas públicas e também na produção de conhecimentos.

Parte-se, portanto, do entendimento de que a metodologia, processual, contribui para aprofundar estudos interpretativos. Por isso, a metodologia reconstrói-se no desenvolvimento da pesquisa, tecendo-se e articulando-se processualmente, considerando o tema estudado, o contexto social e as formas simbólicas circundantes. A pesquisa e este artigo, por sua vez, também são narrativas inacabadas, pois sempre que se quiser podem ser reescritas, reinterpretadas.

Optou-se pela abordagem interpretativa inserida no paradigma da teoria social crítica habermasiana, por constituir-se de possibilidades de refletir eventos sociais cotidianos em que a linguagem é vista como prática social e, portanto, condicionada ao contexto em que é produzida - daí os discursos e as práticas de todos nos processos serem tomados como objetos de interpretação e reinterpretação. As práticas socioculturais nascem da linguagem (signo/forma simbólica), que evidencia os conhecimentos e sentidos produzidos, os quais são mutáveis e distintos e, no processo de interpretação, precisam ser considerados, já que remetem às relações de poder manifestas pelos sujeitos em interação. 
O referencial metodológico está ancorado nos pressupostos enunciados por John Thompson (1995), que, fundamentado na tradição hermenêutica, propõe a hermenêutica profunda (HP). Os processos de compreensão e interpretação são vistos, pois, não como uma dimensão metodológica que exclua radicalmente uma análise formal ou objetiva, mas como uma dimensão, ao mesmo tempo, complementar e indispensável a eles.

No processo de pesquisa, o quotidiano e os ditos dos diferentes sujeitos são importantes, porém Thompson (1995) adverte que não basta fazer a interpretação da doxa (opiniões, crenças e compreensões que são sustentadas e partilhadas pelas pessoas que constituem o mundo social), como se isso fosse o estudo das formas simbólicas. Por isso, sugere uma ruptura metodológica com a hermenêutica da vida quotidiana, ir para outro nível de análise, pois as formas simbólicas são também construções estruturadas de maneira definida e que estão inseridas em condições sociais e históricas específicas.

Thompson (1995) define três fases dentro do enfoque da HP, ou seja, análise sócio-histórica, análise formal ou discursiva e interpretação-reinterpretação. Alerta, no entanto, que a maneira de aplicação e os instrumentos são da escolha do pesquisador. Assim procedeu-se, por isso o uso da metodologia foi adequado ao objeto da investigação e a escolha recaiu naqueles métodos que contribuíram e possibilitaram atender aos objetivos que os autores se propuseram. Este tipo de análise contribuiu para compreender o objeto de estudo, já que possibilita um olhar mais atento a certas falas, além de propiciar o cotejo entre eles. Assim, a interpretação é um processo de síntese criativa, pois envolve a construção ativa do sentido, a explicação criativa do que está representado ou do que é dito, por um processo contínuo de interpretação que procura juntar os resultados da análise sócio-histórica e formal discursiva, mostrando como o sentido das formas simbólicas serve para estabelecer e sustentar relações.

Este artigo constitui-se num recorte de pesquisa mais ampla, que se preocupa com dois processos básicos: a gestão do processo de desenvolvimento local e regional e a construção da cidadania. A gestão social, com ênfase na participação social e nas relações de poder, é foco de análise e, para a compreensão desses processos, consideram-se como locus três espaços públicos básicos: os Comudes, os Coredes e o Fórum dos Coredes.

Os sujeitos que interagiram na construção desta pesquisa são os agentes e sujeitos sociais que atuam no âmbito dos conselhos regionais e municipais de desenvolvimento e/ou que interagem na gestão do processo de desenvolvimento local e regional. Os ditos que se revelaram - por meio dos documentos, falas e narrativas - indicam o conhecimento partilhado por outros elementos da mesma categoria, grupo, problemática ou cultura. Foram utilizados os questionários de avaliação aplicados em 2009, respondidos por 27 Coredes. Empreendeu-se a leitura das Cartas dos Coredes (relatórios anuais de avaliação e planejamento). E, também, realizou-se pesquisa nos registros de atas de reuniões e assembleias, relatórios e documentos elaborados pelos Coredes e pelo Fórum dos Coredes. O recorte abordado neste artigo é uma leitura de aspectos da organização e do funcionamento dos Coredes à luz de uma matriz de categorias e subcategorias construída com base em diversos modelos de análise, conforme se verá a seguir.

\section{Categorias de Análise Para Espaços Públicos e Processos Participativos de Construção de Políticas Públicas}

Diversos estudiosos e grupos de pesquisa têm proposto e adotado matrizes de análise de processos participativos. Entre estas matrizes, encontra-se a proposta da descrição de um conjunto de dez princípios e condicionantes definidos na Declaración de Málaga, no âmbito Red FAL (DECLARACIÓN DE MÁLAGA, 2007). Outra proposta de critérios para avaliação da participação cidadã foi desenvolvida por um grupo de pesquisa vinculado ao Instituto de Governo e Políticas Públicas (IGOP) da Universidade Autônoma de 
Barcelona, que consta de 46 aspectos organizados em 22 critérios e 05 eixos temáticos (JORBA, MARTÍ e PARÉS, 2007; PARÉS e CASTELLÀ, 2008; PARÉS, CASTELLÀ e JORBA, 2007).

O Programa de Estudos em Gestão Social (PEGS) vinculado à Ebape/FGV, com base nos resultados de sua longa trajetória de estudos na área da gestão social e participação cidadã e tendo por base, ainda, os estudos do IGOP, desenvolveu um modelo com 21 critérios organizados em seis categorias de análise, que correspondem aos princípios conceituais da cidadania deliberativa (TENÓRIO, 2007; TENÓRIO et al., 2008, 2010). Utilizada especialmente para a análise de conselhos gestores de políticas públicas, a matriz de categorias de análise de espaços de cidadania interativa considera vinte subcategorias organizadas em seis categorias que abordam o processo de sua criação, organização e funcionamento, a natureza consultiva ou deliberativa, a composição na sua constituição, a autonomia no seu funcionamento, efetividade e eficácia, a publicização do conselho e a capacitação dos conselhos e dos conselheiros (ALLEBRANDT, 2002, 2003, 2006, 2008, 2010).

Considerando os elementos integrantes destas diversas propostas de categorização para a análise e entendimento dos espaços públicos de interação da sociedade com o Estado e tendo presente a organização e a dinâmica do objeto de análise desta pesquisa, desenvolveu-se a seguinte matriz de categorias de análise que orientaram o presente estudo (Quadro 1).

Quadro 1

Categorias de análise de espaços públicos de interação e promoção do desenvolvimento

\begin{tabular}{|c|c|c|}
\hline Categorias & \multicolumn{2}{|c|}{ Subcategorias } \\
\hline \multirow{3}{*}{$\begin{array}{l}\text { Configuração dos } \\
\text { espaços públicos }\end{array}$} & \multicolumn{2}{|c|}{ Ampliado } \\
\hline & \multicolumn{2}{|c|}{ Semirrestrito } \\
\hline & \multicolumn{2}{|c|}{ Restrito } \\
\hline \multirow{4}{*}{$\begin{array}{l}\text { Configuração interna de } \\
\text { poder }\end{array}$} & \multirow{3}{*}{ Composição } & Autônomo \\
\hline & & Paritário \\
\hline & & Homologatório \\
\hline & \multicolumn{2}{|c|}{ Diversidade dos participantes } \\
\hline \multirow{4}{*}{$\begin{array}{l}\text { Natureza dos espaços e } \\
\text { caráter das } \\
\text { deliberações }\end{array}$} & \multicolumn{2}{|c|}{ Consultivo } \\
\hline & \multicolumn{2}{|c|}{ Deliberativo } \\
\hline & \multicolumn{2}{|c|}{ Vinculante } \\
\hline & \multicolumn{2}{|c|}{ Não vinculante } \\
\hline \multirow[t]{3}{*}{ Autonomia } & \multicolumn{2}{|c|}{$\begin{array}{c}\text { Independência (possibilidades de exercer a própria vontade - coletiva e } \\
\text { individual) }\end{array}$} \\
\hline & \multicolumn{2}{|c|}{ Administrativa } \\
\hline & \multicolumn{2}{|c|}{ Financeira } \\
\hline
\end{tabular}




\begin{tabular}{|c|c|c|}
\hline & & Infraestrutura/logística \\
\hline \multirow{7}{*}{ Igualdade participativa } & \multicolumn{2}{|c|}{ Forma de escolha dos representantes } \\
\hline & \multicolumn{2}{|r|}{ Avaliação participativa } \\
\hline & \multicolumn{2}{|c|}{ Canais de divulgação e qualidade da informação } \\
\hline & \multirow{2}{*}{$\begin{array}{l}\text { Processo } \\
\text { decisório }\end{array}$} & Voto universal voluntário dos participantes \\
\hline & & Consenso ou voto dos representantes \\
\hline & \multirow{2}{*}{ Tipo de mandato } & Representação livre \\
\hline & & Representação vinculada \\
\hline
\end{tabular}

Fonte: Elaborado pelos autores com base em Allebrandt, 2002, 2003, 2010; Parés e Castellà, 2008; Parés, Castellà e Jorba, 2007; Tenório, 2007; Tenório et al., 2010.

No que se refere à configuração dos espaços públicos, partiu-se da análise proposta por Allebrandt (2002, 2003), que afirma que, quando um conselho apresenta, em sua estrutura formal, a existência de fóruns, conferências e/ou assembleias públicas, está-se diante do tipo conselho ampliado. Quando, ao contrário, não apresenta nenhum desses mecanismos, é do tipo conselho restrito. Os fóruns, conferências e assembleias públicas são alguns dos principais espaços públicos em que a participação adquire real possibilidade de se constituir em prática de cidadania deliberativa. São esses espaços públicos ampliados que qualificam arranjos institucionais como os conselhos municipais e regionais. Propõe-se, no entanto, uma adequação, com a inclusão de mais uma subcategoria, os espaços semirrestritos. Assim, essa categorização possibilita classificar os diferentes espaços que compõem uma dinâmica social mais ampla, como a promoção do desenvolvimento regional e local. Pode-se classificar uma instituição de forma global, como, por exemplo, um conselho regional, ou pode-se enquadrar os diferentes mecanismos e espaços que integram ou se relacionam à arquitetura organizacional de determinado espaço ou processo interativo. Está presente a concepção de que a maior abertura dos processos participativos favorece a articulação dos interesses dos cidadãos e amplia e qualifica suas condições na tomada de decisões (TENÓRIO et al., 2008) e caracteriza o princípio de inclusão inerente aos processos de cidadania deliberativa (LÜCHAMNN, 2002a, 2002b, 2007; TENÓRIO, 2007; TENÓRIO et al., 2008, 2010).

Com relação à configuração interna de poder, é importante conhecer a composição formal das diferentes instâncias que compõem a estrutura dos espaços públicos, pois ela caracteriza em que medida os espaços incorporam e praticam o princípio do pluralismo necessário nos processos de cidadania deliberativa. A composição em si, ainda que garanta a multiplicidade de atores, a presença dos diferentes segmentos da sociedade e a presença majoritária da sociedade civil, não é condição suficiente para garantir o efetivo funcionamento dos conselhos, mas é um dos elementos cruciais que permitem e facilitam melhor desempenho e efetividade das ações. Com base na tipologia proposta por Allebrandt (2002), propõe-se aqui uma categorização de três tipos básicos de espaço: autônomo, paritário e homologatório. ${ }^{10} \mathrm{O}$ primeiro tipo,

\footnotetext{
10 Allebrandt (2002, 2003), considerando as experiências existentes no país, relatadas em estudos descritivos e analisadas em pesquisas, propõe a seguinte classificação: conselho paritário, conselho tripartite, conselho tripartite paritário, conselho tetrapartite, conselho tetrapartite paritário, conselho técnico-corporativo, conselho governo-sociedade ou homologado e conselho sociedadegoverno ou autônomo. Outros estudiosos (CARVALHO et al., 1999; GOMES, 2000; GOHN, 2001) também elaboram tipologias classificatórias voltadas à análise de conselhos gestores.
} 
autônomo, garante a hegemonia da sociedade civil na composição do espaço. O tipo paritário caracteriza aqueles espaços ou instâncias que, em termos de sua composição, definem um equilíbrio de poder entre o Estado e a sociedade, já que cada um ocupa metade das vagas definidas para cada espaço ou instância. O terceiro tipo, homologatório, apresenta em sua composição a presença majoritária do Estado. Característico de muitos conselhos setoriais locais, como os conselhos de defesa civil, tende a se pautar pela lógica estatal no processo decisório relativo às políticas públicas. Além de classificar os espaços em termos de grandes segmentos, é fundamental conhecer a diversidade dos participantes, verificando quais segmentos, setores, entidades, associações e movimentos sociais integram essas composições, qualificando os sujeitos que participam nas diferentes instâncias decisórias dos processos de discussão e promoção do desenvolvimento local e regional e que impactam e/ou definem as políticas públicas locais e regionais.

A natureza dos espaços e o caráter das deliberações referem-se ao tipo e grau de participação praticados nos espaços públicos. Os processos participativos apresentam diferentes graus de participação. Parés, Castellà e Jorba (2007) adotam uma escala de cinco níveis para mensurar o grau de participação: informação, comunicação, consulta, deliberação e decisão. No entanto, os processos centrados apenas em informação e/ou comunicação não podem ser considerados processos participativos, ainda que ambos sejam elementos importantes e necessários a qualquer processo participativo. Deste modo, é importante verificar se estão sendo praticados processos de consulta (basicamente solicitando informações sobre prioridades e necessidades), de deliberação (com discussão sobre as propostas, previsão e avaliação de alternativas) ou de decisão, quando também se permite que os cidadãos e as organizações decidam e gerenciem o próprio processo e os resultados derivados. Quando se trata de processos de promoção do desenvolvimento local e regional, um aspecto crucial é o caráter das deliberações quanto à obrigatoriedade ou não de o Estado cumprir as determinações decorrentes dos processos participativos, isto é, se as decisões são vinculantes ou não vinculantes. Esta situação está presente sempre que processos participativos discutem e deliberam sobre os orçamentos públicos. Quando existe o caráter vinculante, as demandas e/ou recursos definidos no processo obrigam o poder executivo das diferentes esferas de governo a incluí-los na peça orçamentária. Quando não estiver presente o caráter vinculante, ainda que possa fazê-lo, o Executivo não é obrigado a incluir as demandas no orçamento, cabendo-lhe o livre arbítrio.

Outro aspecto do modelo de análise é a autonomia, um dos princípios presentes na própria concepção da cidadania deliberativa (LÜCHMANN, 2002a, 2007) e fundamental para que os problemas locais e regionais sejam avaliados e soluções sejam encaminhadas pelas próprias comunidades (TENÓRIO et al., 2010). Propõe-se, aqui, a análise de uma categoria de caráter substantivo, que é a possibilidade de os cidadãos exercerem a própria vontade, ou seja, trata-se de verificar a independência dos espaços públicos ou das instâncias e processos em que se delibera e decide. Entende-se que a existência efetiva de independência nos processos coloca em segundo plano a origem das proposições, outra categoria considerada importante em outros modelos para mensurar a autonomia. Incorporam-se também ao modelo as categorias propostas por Allebrandt (2002, 2003), especificamente a autonomia administrativa, financeira e de infraestrutura e logística dos espaços públicos. A falta de autonomia fragiliza a dinâmica de funcionamento desses espaços, tornando-os, muitas vezes, ineficazes como mecanismos da democracia deliberativa.

A igualdade participativa, outro princípio inerente ao conceito de cidadania deliberativa, é o quinto aspecto do modelo de análise proposto. A igualdade participativa pode ser avaliada em relação a determinado espaço público, como o caso dos conselhos regionais ou municipais, em relação a instâncias específicas desses espaços e/ou aos processos participativos em desenvolvimento em determinado território. A forma de escolha dos representantes dos diferentes segmentos ou entidades em determinado espaço é um dos fatores que contribuem para a legitimação dos processos e espaços públicos. Não basta, no entanto, uma composição plural dos diferentes espaços, é importante também conhecer como foi o processo de escolha daqueles que ocupam o espaço em determinado momento. Outra categoria diz respeito à avaliação participativa. A ausência de avaliação dos processos participativos é considerável e, muitas vezes, responsável pela falta de 
efetividade das dinâmicas participativas na sociedade. A avaliação é importante não só porque incorpora a visão dos participantes, mas também porque abre espaços para a reflexão, o aprendizado e a apropriação do processo participativo. As avaliações participativas implicam também uma transferência de poder para outros agentes. Trata-se, portanto, de uma prática que fortalece o poder dos cidadãos, pois a avaliação, como as demais práticas participativas, implica uma vontade de partilhar, negociar, entrar em consenso e gerir mudanças (JORBA, MARTÍ e PARÉS, 2007). Como lembra Lüchmann (2002a), situações de desigualdades também ocorrem no que se refere ao conhecimento e informação, e, neste sentido, os agentes governamentais apresentam forte influência no processo decisório. Por isso, a igualdade participativa resulta também da qualidade da informação, fundamental para o nivelamento das oportunidades de atuação dos diferentes participantes nos processos decisórios (TENÓRIO et al., 2010). Assim, conhecer e avaliar os canais utilizados para veicular a informação também se torna crucial. Outra categoria a analisar diz respeito ao processo decisório propriamente dito, ou seja, como e quem toma as decisões. É utilizado o critério do voto universal voluntário dos participantes envolvidos ou do voto dos representantes escolhidos para determinado espaço e/ou processo. Além disso, convém também analisar o tipo de mandato dos representantes, isto é, trata-se de representação livre, quando o detentor do mandato tem liberdade para tomar decisões com base no processo de discussão ou de representação vinculada, em que o detentor possui mandato imperativo e deve atuar como delegado vinculado às decisões anteriores das assembleias públicas ou outras instâncias.

\section{Os Conselhos Regionais de Desenvolvimento do Rio Grande do Sul}

A temática dos Conselhos Regionais de Desenvolvimento (Coredes) e, mais recentemente, dos Conselhos Municipais de Desenvolvimento (Comudes) tem marcado presença nos espaços sociais, políticos e econômicos e, ainda que não na mesma intensidade, nos espaços acadêmicos gaúchos ao longo das últimas décadas. Como afirma Frantz (2004, p. 9), processa-se algo de novo no cenário do poder político do Estado do Rio Grande do Sul. Para este autor, o algo de novo é "[...] um processo de educação política pela participação no debate sobre o desenvolvimento regional", é a construção de novas relações políticas, com a entrada em cena de novos atores sociais, "[...] no cenário das relações políticas com o objetivo de construir e ampliar os espaços públicos de participação".

Conforme indicam alguns estudiosos das questões de desenvolvimento (NYGAARD, 1990; RÜCKERT, 2002; VEIGA, 2006), no Rio Grande do Sul, entre as décadas de 1970 e 2000, surgiram três propostas de regionalização direcionadas ao planejamento do desenvolvimento regional. ${ }^{11}$ A primeira foi o Sistema de Desenvolvimento Regional Urbano (Sisdru), do governo Triches (1971/1974), no período de ditadura militar e contemporâneo do II Plano Nacional de Desenvolvimento (II PND) em nível nacional; a segunda, já no período de redemocratização do governo Simon (1986/1990), foi o Programa de Descentralização Regional; a terceira foi a proposta dos Coredes, que surgiu no período de campanha eleitoral para governador, em 1990. As duas primeiras propostas de divisão regional tinham uma preocupação de absorver e promover a estrutura regionalizada do governo estadual, além de implantar, em cada região, um processo de planejamento para o seu desenvolvimento. A terceira também buscava a implantação de processo de

\footnotetext{
${ }^{11}$ Nos últimos anos (2004-5), surge uma quarta proposta de regionalização, decorrente do Estudo Rumos 2015, realizado no governo Rigotto: as Regiões Funcionais de Planejamento, Visa à organização do processo de planejamento do desenvolvimento, em especial se constituindo em regiões para o planejamento das políticas públicas por parte do Estado. Esta regionalização, que divide o Estado em nove regiões, no entanto, compõe-se de múltiplos dos Coredes, mantendo, assim, a divisão territorial destes, aglutinando-os em dois, três ou quatro, para efeitos do processo de planejamento do estado. O PPA 2008-2011 do estado foi elaborado de forma regionalizada pelas Regiões Funcionais, tendo sido, inclusive, elaborados e publicados os Cadernos Regionais do PPA.
} 
planejamento e gestão do desenvolvimento regional, mas sua centralidade está mais na participação da sociedade neste processo e menos na estruturação da máquina pública de forma regionalizada. As duas primeiras propostas não chegaram a ser concretizadas. Já a proposta dos Coredes foi implantada gradativamente a partir de 1991 e se encontra em desenvolvimento até hoje, tendo sobrevivido a cinco governos estaduais e atuando, no presente, em parceria com o sexto governo.

A discussão sobre o desenvolvimento regional no Rio Grande do Sul já vinha sendo levada a efeito no final dos anos 80 do século passado com forte envolvimento de alguns atores sociais regionais (especialmente as universidades comunitárias e parcela do empresariado mobilizado por elas). Exemplo disso é a discussão sobre a regionalização dos recursos públicos estaduais na área da ciência e tecnologia, ainda no governo Simon (1987-1990), com a criação descentralizada de Polos de Modernização Tecnológica, cujas bases se firmaram nas universidades comunitárias gaúchas.

Em 1990, durante o processo de campanha para o governo do estado, a questão da regionalização estava presente. O governador eleito, Alceu Collares, do PDT, previa, no seu Plano de Governo Povo Grande do Sul, a proposta de criação de conselhos regionais de desenvolvimento, como órgãos auxiliares de ação de governo. De acordo com Fernandes (2005), o que se imaginava na proposta de constituição dos conselhos regionais era a criação de um espaço descentralizado de decisão, aberto à participação plural, com suporte técnico para decidir considerando as restrições, com decisões baseadas nas políticas públicas do Governo em exercício e assumindo corresponsabilidade nas decisões.

Em 1991, inicia-se o processo de criação dos Coredes, ainda que sua institucionalização legal aconteça apenas em 1994, pela Lei 10.283, de 17 de outubro, e sua regulamentação, pelo Decreto 35.764, de 29 de dezembro do mesmo ano, já no final do governo Collares.

Já no final de 1991, os 13 Coredes então existentes propuseram organizar um fórum estadual dos conselhos, que passou a funcionar regularmente a partir de março de 1992. O Fórum dos Conselhos, integrado pelos presidentes e outros membros dos Coredes, reúne-se ordinariamente uma vez por mês, normalmente em Porto Alegre, e é o principal espaço de interação com o governo estadual, com a Assembleia Legislativa e com as estruturas do aparelho de Estado, além de se constituir no espaço de deliberação do movimento corediano estadual.

O Estado do Rio Grande do Sul está dividido territorialmente em 496 municípios autônomos, que se constituem, juntamente com o estado, em entes federados da República Federativa do Brasil. Organizados inicialmente em 21, hoje são 28 os Coredes (Figura 1) em que se divide o território gaúcho, respeitando sempre o limite territorial oficial dos municípios que integram cada um deles. Ainda que alguns conselhos municipais de desenvolvimento tenham sido criados no início da década de 1990 ou até antes, a grande maioria dos municípios criou os seus Comudes a partir de 2003. 


\section{Mapa dos 28 Coredes gaúchos e suas regiões de abrangência}

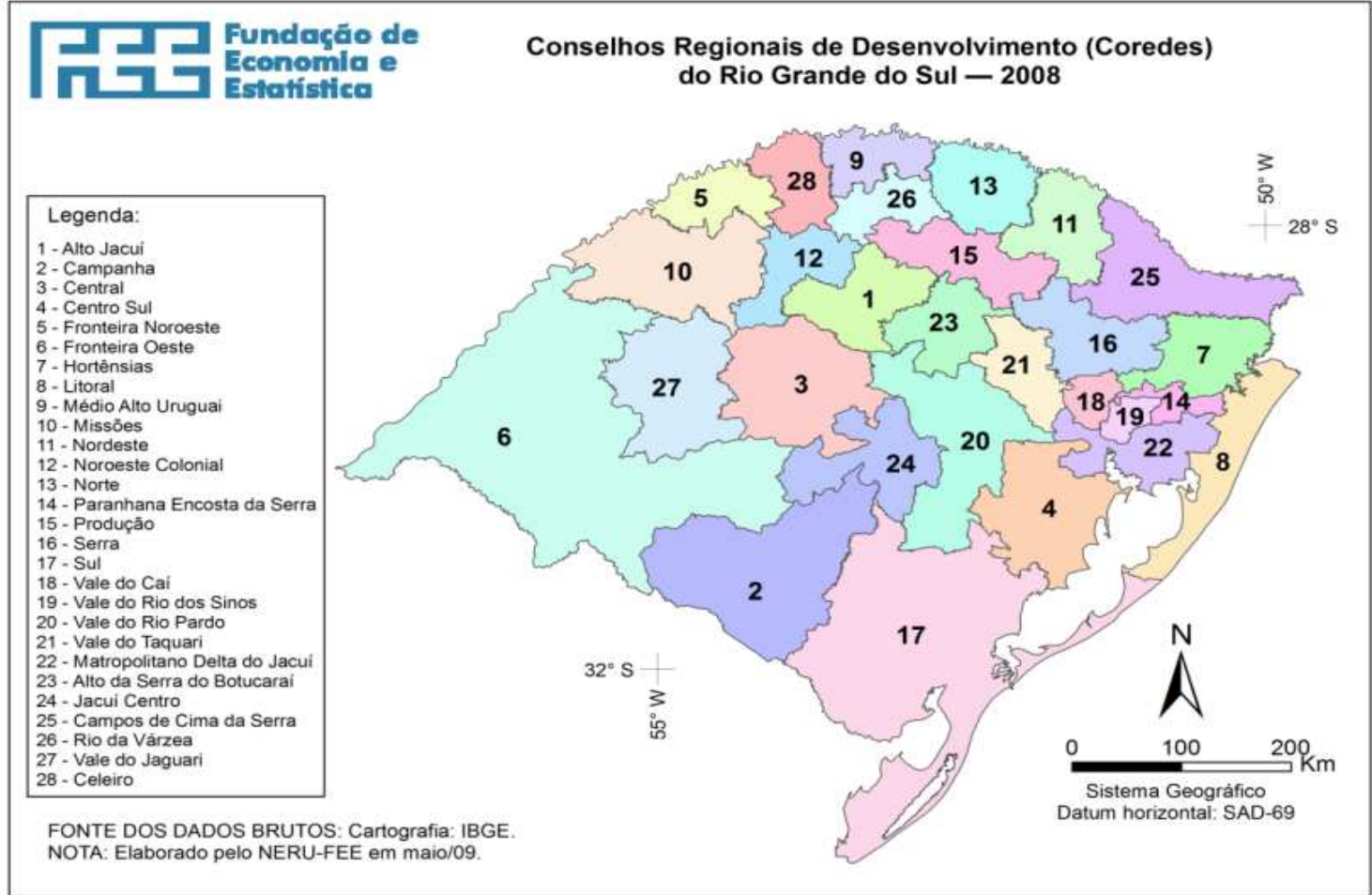

Fonte: MAPAS-FEE, 2010

No governo Britto (PMDB-PSDB), os Coredes só conseguiram espaço mais efetivo no último ano de governo, quando foi realizada a Consulta Popular (CP) instituída pela Lei 11.179, de 25/06/98, dispondo sobre a consulta direta popular quanto à destinação de percentual do orçamento estadual voltado para investimentos de interesse regional.

Seguiu-se o governo de Olívio Dutra (PT), que adotou a dinâmica do Orçamento Participativo Estadual (OPE) como instrumento político-administrativo de gestão. A proposta inicialmente implantada pelo governo do estado excluía os Coredes do processo do OPE, contrariando compromissos de campanha. Após negociação empreendida pelo Fórum Estadual dos Coredes com o novo governo, em maio de 1999 foi assinado Protocolo de Cooperação entre o governo do estado e os Coredes, instituindo trabalho em parceria na promoção do OPE. Esta parceria, no entanto, aconteceu de forma precária, mais exitosa em algumas regiões, menos em outras, de acordo com as condições objetivas (em especial pela postura políticoideológica dos coordenadores regionais do OPE e/ou dos dirigentes dos Coredes) de cada caso.

Este fato, no entanto, foi positivo por alertar o Coredes sobre o seu real papel na dinâmica da sociedade gaúcha. A reflexão interna ensejada foi fundamental para reafirmar o seu principal objetivo: a promoção do desenvolvimento regional. A participação no processo de definição e alocação dos recursos orçamentários (seja na forma de Consulta Popular ou de Orçamento Participativo), ainda que importante e fundamental, constituía-se apenas uma das ações dos Coredes. Por isso, no período de 2000 a 2002, os Coredes priorizaram entre suas metas: elaboração e implantação de planos estratégicos de desenvolvimento regional; a promoção de interesses das regiões nas instâncias dos governos estaduall e federal (isto resultou na 
implantação de duas Mesorregiões: Grande Fronteira Mercosul e Metade Sul); implantação dos conselhos municipais de desenvolvimento (Comudes) em cada município gaúcho; e a organização e consolidação de três macrorregiões no território gaúcho (norte, nordeste e sul).

O governo estadual de Rigotto (PMDB-PSDB) substituiu o OPE pelo Processo de Participação Popular (PPP), entregando a coordenação do processo de discussão, definição e alocação dos recursos orçamentários aos Coredes, no âmbito regional, e aos Comudes, no âmbito municipal. Como afirmou Becker (2003, p. 8), no início do novo governo, " [...] o aperfeiçoamento dos Coredes implica absorver o aprendizado obtido por meio da experiência do orçamento participativo, da mesma forma como implica aprender com a metodologia da consulta popular, praticada no governo Britto". Assim, os Coredes e o novo governo preocuparam-se em aperfeiçoar o processo, mantendo e qualificando as virtudes e superando as deficiências das experiências anteriores. De acordo com Allebrandt (2010), o desenho da CP estabelecido em 2003 e aperfeiçoado nos anos subsequentes pode ser caracterizado como um modelo híbrido entre o OPE do período 1999/2002 e a CP de 1998.

No governo de Yeda Crusius, depois de demorada discussão sobre a continuidade da realização das consultas populares devido à falta de cumprimento por parte dos governos no tocante à execução dos projetos votados e incluídos nos orçamentos estaduais, Coredes e governo firmaram um acordo em que os primeiros aceitam a diminuição dos valores destinados à $\mathrm{CP}$ e o segundo se compromete a liquidar o passivo deixado por governos passados em relação aos projetos eleitos pelas regiões, bem como priorizar efetivamente a execução dos projetos eleitos nas novas consultas. Esse acordo foi parcialmente cumprido, em especial nos primeiros dois anos do governo. No final do governo, no entanto, acumula-se novo passivo decorrente da não execução das últimas parcelas do passivo negociado e dos valores votados em 2008 e 2009.

Os Coredes, apesar das dificuldades de toda ordem, conseguem sobreviver e consolidar-se ao longo de cinco governos estaduais. Neste início de governo Tarso, sexto governo que convive com a experiência dos Coredes, o movimento tem expectativas de avanços diante da manifestação reiterada do novo governo de instituir um sistema de participação cidadã no estado, incorporando todas as práticas e experiências que foram/vêm sendo praticadas nos últimos anos. Este sistema está, até o momento, sendo construído de forma coletiva, a exemplo da realização do Seminário do Sistema Estadual de Participação Cidadã: Bases Conceituais, realizado no mês de fevereiro de 2011. Ao mesmo tempo que o novo governo desencadeava o processo de elaboração participativa do Plano Plurianual (PPA) -2012/2015, com a efetiva participação dos Coredes na organização dos Seminários Regionais organizados nas nove Regiões Funcionais de Planejamento, uma Comissão Estadual integrada por representantes do Fórum dos Coredes e integrantes da Seplag-RS desenvolviam estudos e debates visando elaborar a proposta do novo modelo de participação da sociedade no planejamento estadual e regional com vistas à alocação de recursos orçamentários.

A experiência gaúcha, apontada como a experiência de desenvolvimento regional mais avançada do Brasil (BANDEIRA, 1999, 2003, 2004; VEIGA, 2006b), constitui-se num complexo sistema adaptativo institucional composto por organizações, no âmbito estadual, de recorte municipal (496 Comudes), regional (28 Coredes), e macrorregional (09 regiões funcionais de planejamento). Este sistema passa a interagir com outros arranjos decorrentes de políticas de âmbito federal, como o Programa de Sustentabilidade de Espaços Sub-regionais (MesoSul e MesoMercosul), Territórios Rurais e Territórios da Cidadania.

Uma Leitura à Luz das Categorias de Análise

Quando se analisam os Coredes e o Fórum dos Coredes no que se refere à configuração dos espaços públicos, considerando a existência de diversos espaços, alguns podem ser classificados como ampliados e 
abertos à participação de qualquer cidadão; outros, classificados como mais restritos, nos quais participam os representantes ou delegados indicados ou eleitos. Da análise dos diferentes espaços com base no marco legal, em relatórios, documentos e entrevistas realizadas, propõe-se a sua classificação, dada sua função e dinâmica na arquitetura organizacional dos conselhos, em espaços ampliados, semirrestritos e restritos (Quadro 2).

Quadro 2

O movimento corediano e a configuração dos espaços públicos

\begin{tabular}{|c|c|c|}
\hline Aspectos & Categorias & Espaços/Processos \\
\hline \multirow{12}{*}{$\begin{array}{l}\text { Configuração dos } \\
\text { espaços públicos }\end{array}$} & \multirow{5}{*}{ Ampliado } & Assembleias Públicas Municipais \\
\hline & & Assembleias Regionais Ampliadas \\
\hline & & Consulta Popular \\
\hline & & Audiências Públicas do FDDR \\
\hline & & Assembleias Públicas de Planejamento Estratégico \\
\hline & \multirow{3}{*}{ Semirrestrito } & Assembleias do Fórum dos Coredes-RS \\
\hline & & Assembleias Gerais dos Coredes \\
\hline & & Reuniões dos Conselhos de Representantes dos Coredes \\
\hline & \multirow{4}{*}{ Restrito } & $\begin{array}{l}\text { Reunião ampliada da Diretoria Executiva do Fórum } \\
\text { (participação do Conselho Deliberativo e outros) }\end{array}$ \\
\hline & & Reuniões da Diretoria Executiva do Fórum \\
\hline & & Reuniões das Diretorias Executivas dos Coredes \\
\hline & & Comissão Estadual da CP \\
\hline
\end{tabular}

Fonte: Allebrandt (2010, p. 207).

A Consulta Popular, entendida aqui como a etapa final do processo de participação da sociedade civil na definição e escolha de projetos a integrarem o Orçamento Anual do Estado, constitui-se, sem dúvida, no espaço mais ampliado de todos, de natureza quase plebiscitária. Uma crítica muitas vezes externada é a de que a CP seria instrumento típico de democracia representativa e não participativa. Entende-se, entretanto, que este argumento não é válido, uma vez que a CP é apenas a etapa final de um processo em que a cidadania está presente e que, portanto, como processo decisório, é altamente eficaz, desde que garantida a efetividade das políticas eleitas pela população. Também as etapas preparatórias desse processo, em que se realizam as assembleias públicas municipais e assembleias regionais ampliadas, apresentam esta característica. Nas críticas feitas pelos defensores do Orçamento Participativo como o modelo ideal para garantir a participação universal voluntária dos cidadãos, considera-se que o modelo do Processo de 
Participação Popular/Consulta Popular elitiza o processo, não garantindo a participação universal voluntária. Para os críticos do Orçamento Participativo, no entanto, a participação universal voluntária seria, em boa medida, resultante da atuação da estrutura dos partidos aliados do governo que implementa o OP. Apesar dessas críticas, entende-se que o OP é um instrumento mais eficaz no que se refere ao processo de mobilização e discussão, antes do processo decisório propriamente dito. Por isso, ampliar a participação universal e voluntária do cidadão na fase preparatória do processo, especialmente nas assembleias públicas municipais, é um desafio para o processo coordenado pelos Coredes e Comudes.

No caso das Assembleias Regionais Ampliadas, é a participação dos delegados que as qualifica. Como os delegados são eleitos nas assembleias municipais, mais uma vez constata-se que o processo depende muito da dinâmica no âmbito local.

Um segundo grupo de espaços pode ser categorizado como semirrestrito, pois são abertos à participação de qualquer cidadão interessado, mas, quando não obtido o consenso para as deliberações, adota-se processo de votação, no qual apenas os representantes oficiais participam. É o caso da Assembleia do Fórum dos Coredes-RS, das assembleias dos Coredes e das reuniões dos Conselhos de Representantes dos Coredes.

Como espaços mais restritos podem ser listadas as reuniões das diretorias executivas dos Coredes e do Fórum dos Coredes. Ainda assim, é necessário lembrar que, muitas vezes, essas reuniões também são ampliadas com a presença dos integrantes das comissões setoriais, no caso dos Coredes; ou dos integrantes do Conselho Deliberativo, no caso do Fórum dos Coredes. Também a Comissão Estadual da Consulta Popular se enquadra como espaço restrito. As reuniões nesse grupo normalmente não são abertas a outros participantes, ainda que não se exclua a participação sem direito a voto.

O problema que pode ser apontado quanto aos espaços semirrestritos é que, mesmo sendo abertos à participação, normalmente não há incentivo explícito nesse sentido. Frequentemente, as reuniões são convocadas apenas por meio de correio eletrônico ou correspondência, sem divulgação pública na mídia ou em portal de acesso público, o que diminui a possibilidade de participação voluntária nesses espaços.

Quanto à configuração interna de poder das diversas instâncias dos Coredes e de outros espaços com os quais se relacionam, considerando a composição dos arranjos, pode-se afirmar que a maioria deles se enquadra no modelo denominado autônomo, conforme se verifica no enquadramento proposto no Quadro 3.

O Fórum dos Coredes é formalmente integrado pelos presidentes dos 28 conselhos. Na prática, no entanto, funciona com a participação de todos os integrantes das diretorias executivas ou, ainda, com a participação de técnicos das equipes de apoio dos conselhos. Apenas em momentos muito específicos, como nas eleições da diretoria do Fórum, há um controle mais rígido da participação dos presidentes na Assembleia.

A configuração da estrutura organizacional dos conselhos evidencia que o processo de sua criação conduziu a desenhos bastante diversos em termos de composição dos dois principais órgãos deliberativos: as assembleias gerais e os conselhos de representantes. 


\section{Quadro 3}

\section{O movimento corediano e a configuração interna de poder dos espaços públicos de interação}

\begin{tabular}{|c|c|c|}
\hline Aspectos & Categorias & Espaços/Processos \\
\hline \multirow{4}{*}{$\begin{array}{l}\text { Configuração } \\
\text { interna de poder }\end{array}$} & \multirow{3}{*}{ Autônomo } & Fórum dos Coredes \\
\hline & & $\begin{array}{l}\text { Assembleias, Conselhos de Representantes e Diretorias } \\
\text { Executivas dos Coredes }\end{array}$ \\
\hline & & $\begin{array}{l}\text { Assembleias Públicas Municipais, Assembleias Regionais } \\
\text { Ampliadas do PPP/CP }\end{array}$ \\
\hline & Paritário & Comissão Estadual da CP (paridade Governo/Sociedade) \\
\hline
\end{tabular}

Fonte: Allebrandt (2010, p. 209).

Entre as assembleias gerais ou assembleias regionais gerais, como são denominadas em diversos Coredes, encontram-se algumas cuja composição privilegia os órgãos estatais, com pouca presença de entidades da sociedade civil. É o caso, por exemplo, do Corede Missões, cuja assembleia é composta pelos prefeitos (25) e presidentes das câmaras de vereadores (25), de um representante de cada órgão público federal e estadual (que, na região, passam de dez), além dos deputados federais e estaduais com domicílio eleitoral na região de abrangência do Corede. Além desses membros (cerca de sessenta), integra a assembleia um representante de cada Comude organizado (25), que representa a sociedade civil. Apesar da argumentação de dirigentes desse Corede de que a pluralidade partidária presente entre prefeitos e presidentes de câmaras de vereadores garante a autonomia do processo e de que os Comudes são os organismos mais representativos da sociedade civil, entende-se que uma configuração desse tipo fragiliza o processo de discussão do desenvolvimento, dada a baixa presença de segmentos e entidades integrantes da sociedade civil organizada - em especial, no caso do Corede Missões, que não possui em sua estrutura o conselho de representantes, presente nos demais conselhos. Assim, a Diretoria Executiva, de apenas quatro membros, é responsável pela maioria das decisões, já que o Estatuto prevê apenas duas assembleias gerais ordinárias por ano.

No outro extremo, pode-se exemplificar com o desenho da assembleia geral regional do Corede Rio da Várzea, cuja composição, além dos prefeitos (17), presidentes das Câmaras de Vereadores (17), presidentes de Comudes (17) e dos deputados federais e estaduais com domicílio eleitoral na sua região de abrangência, contempla representantes de qualquer entidade civil formalmente organizada e devidamente habilitada e todo e qualquer cidadão residente e domiciliado na região, devidamente credenciado. Ou seja, nesse caso, podem participar da assembleia, potencialmente, todos os habitantes da região, desde que credenciados. O Conselho de Representantes do Corede Rio da Várzea, órgão deliberativo de primeira instância, eleito pela Assembleia Geral Regional, é composto por cerca de oitenta membros. Além dos prefeitos, presidentes de Câmaras de Vereadores e Comudes (51 membros) e dos parlamentares, integram o Conselho mais 22 representantes, sendo um por segmento: funcionários públicos; trabalhadores rurais, do comércio, da indústria e do turismo; empresários rurais, do comércio, da indústria; cooperativas; conselhos municipais setoriais, associações de moradores, movimentos ambientalistas, profissionais liberais, instituições financeiras; ensino superior, fundamental, médio e profissionalizante; área da saúde, saúde pública, assistência social e segurança pública.

Diversos Coredes, mesmo não tendo em sua estrutura assembleias com a amplitude deste último, apresentam ampla representatividade de vários segmentos da sociedade. É o caso do Corede Sul, cuja assembleia é composta por cerca de 400 membros. Com 22 municípios em sua área de abrangência, participam da 
assembleia um representante por município dos conselhos municipais setoriais, três representantes por município dos sindicatos das classes trabalhadoras e três dos sindicatos da classe empresarial. Também compõem a assembleia dois representantes por município das associações de moradores (sendo um urbano e um rural), um representante por município das cooperativas, um dos funcionários públicos, um de cada Comudes, os prefeitos, os presidentes de câmaras de vereadores, os reitores de universidades que atuam na região, os dirigentes de entidades voltadas a atividades de desenvolvimento (Embrapa, Emater, Agência de Desenvolvimento da Lagoa Mirim), os parlamentares federais e estaduais com domicilio eleitoral na região e três representantes por município da sociedade civil organizada (entidades religiosas e culturais, clubes de serviços, de promoção social, entidades de profissionais liberais e similares). O Conselho de Representantes desse Corede mantém esta mesma composição, agora com um, dois ou três representantes de cada segmento, também com ampla maioria dos representantes da sociedade civil.

O Corede Delta do Jacuí, cuja assembleia pode chegar potencialmente a mais de 600 participantes, mantém uma composição semelhante à do Corede Sul no que se refere aos segmentos da sociedade civil, incluindo, ainda, representantes de centros de tradições gaúchas, de creches e de grêmios estudantis. Também participam como membros natos na assembleia desse Corede todos os vereadores ativos nos poderes legislativos dos municípios que integram sua região de abrangência, ou seja, 130 vereadores. Da mesma forma, integra a assembleia um representante de cada conselho municipal, o que deve superar mais de 200 representantes. Também os partidos políticos podem indicar representantes para a assembleia.

O Corede-Norc é outro conselho que possui uma assembleia com presença significativa de segmentos da sociedade civil de até 130 integrantes, com ênfase nos conselhos municipais setoriais e programáticos, nas associações de moradores, nos movimentos sociais de caráter regional, cooperativas e partidos políticos. Como em outros conselhos, porém, os trabalhadores rurais, trabalhadores urbanos, empresários rurais e empresários urbanos indicam apenas um representante por segmento, representação esta que poderia ser ampliada para um representante por tipo de sindicato/área. Nesse Corede, o Conselho de Representantes tem a participação majoritária dos coordenadores ou presidentes dos Comudes, que ocupam mais da metade das vagas.

A maioria dos Coredes possui uma Diretoria Executiva composta por quatro membros (um presidente, um vice-presidente, um secretário e um tesoureiro). Alguns Coredes ampliaram as diretorias executivas com dois vice-presidentes (cinco membros) ou com dois vice-presidentes e/ou dois secretários e dois tesoureiros (seis ou sete membros).

Assim, como se demonstra na Tabela 1, as diretorias executivas dos Coredes são compostas por 28 presidentes, 33 vice-presidentes e 71 secretários e tesoureiros, num total de 132 integrantes das diretorias dos 28 Coredes. Os dados evidenciam que, em 50\% dos Coredes, a presidência destes era ocupada pelos representantes das Instituições de Ensino Superior (IES) em 2008/9.

Os representantes de IES ocupam, ainda, seis das vice-presidências $(18,2 \%)$ e oito vagas dos demais cargos $(11,3 \%)$, sendo que, no total, ocupam $21,2 \%$ dos cargos das diretorias executivas dos Coredes. Três presidentes $(10,7 \%)$ são representantes de movimentos sociais, três são ex-prefeitos e dois são vereadores.

Ainda que ocupem apenas a presidência de um Corede, os prefeitos e vice-prefeitos são o segundo segmento mais presente nas diretorias executivas, ocupando 22 cargos $(16,7 \%)$ no total, sendo quinze vicepresidências $(45,5 \%)$. Tanto as IES quanto os governos locais têm se constituído nas principais forças dos Coredes ao longo de sua trajetória. Já o terceiro segmento, com 15,2\% dos cargos, sendo 8 vice-presidências $(24,2 \%)$, é o dos presidentes ou coordenadores dos Comudes, que passou a ter importância nos últimos anos. Criados, em sua maioria, a partir de 2003, com um papel pontual no processo da Consulta Popular, os Comudes vêm aumentando sua importância na dinâmica dos Coredes. 
Tabela 1

Composição das diretorias executivas dos Coredes $-2008 / 9$

\begin{tabular}{|c|c|c|c|c|c|c|c|c|}
\hline \multirow{3}{*}{$\begin{array}{c}\text { Órgãos/entidades/segmentos que } \\
\text { representam }\end{array}$} & \multicolumn{8}{|c|}{ Integrantes das Diretorias Executivas } \\
\hline & \multicolumn{2}{|c|}{ Presidentes } & \multicolumn{2}{|c|}{$\begin{array}{l}\text { Vice- } \\
\text { Presidentes }\end{array}$} & \multicolumn{2}{|c|}{$\begin{array}{l}\text { Secretários/ } \\
\text { Tesoureiros }\end{array}$} & \multicolumn{2}{|c|}{ Total } \\
\hline & no & $\%$ & $\mathrm{n}$ - & $\%$ & $\mathrm{n}$ - & $\%$ & no & $\%$ \\
\hline $\begin{array}{l}\text { IES (principalmente universidades } \\
\text { comunitárias) }\end{array}$ & 14 & $50,0 \%$ & 6 & $18,2 \%$ & 8 & $11,3 \%$ & 28 & $21,2 \%$ \\
\hline Prefeitos/Vices & 1 & $3,6 \%$ & 15 & $45,5 \%$ & 6 & $8,5 \%$ & 22 & $16,7 \%$ \\
\hline Comudes & 0 & $0,0 \%$ & 8 & $24,2 \%$ & 12 & $16,9 \%$ & 20 & $15,2 \%$ \\
\hline $\begin{array}{l}\text { Servidores de Órgãos Estatais } \\
\text { Municipais }\end{array}$ & 1 & $3,6 \%$ & 0 & $0,0 \%$ & 17 & $23,9 \%$ & 18 & $13,6 \%$ \\
\hline $\begin{array}{l}\text { Sindicatos de Trabalhadores/ Centrais } \\
\text { Sindicais/Associações de } \\
\text { Moradores/Outros Movimentos Sociais }\end{array}$ & 3 & $10,7 \%$ & 1 & $3,0 \%$ & 4 & $5,6 \%$ & 8 & $6,1 \%$ \\
\hline Vereadores & 2 & $7,1 \%$ & 0 & $0,0 \%$ & 4 & $5,6 \%$ & 6 & $4,5 \%$ \\
\hline $\begin{array}{l}\text { Servidores Associações de } \\
\text { Municípios/Consórcios Intermunicipais }\end{array}$ & 1 & $3,6 \%$ & 0 & $0,0 \%$ & 4 & $5,6 \%$ & 5 & $3,8 \%$ \\
\hline $\begin{array}{l}\text { Empresários, Profissionais Liberais e } \\
\text { associações empresariais }\end{array}$ & 0 & $0,0 \%$ & 1 & $3,0 \%$ & 4 & $5,6 \%$ & 5 & $3,8 \%$ \\
\hline Servidores de Órgãos Estatais Estaduais & 1 & $3,6 \%$ & 1 & $3,0 \%$ & 2 & $2,8 \%$ & 4 & $3,0 \%$ \\
\hline Ex-Prefeitos & 3 & $10,7 \%$ & 0 & $0,0 \%$ & 0 & $0,0 \%$ & 3 & $2,3 \%$ \\
\hline $\begin{array}{l}\text { Fundações e Agências de } \\
\text { Desenvolvimento }\end{array}$ & 0 & $0,0 \%$ & 0 & $0,0 \%$ & 3 & $4,2 \%$ & 3 & $2,3 \%$ \\
\hline Servidores de Órgãos Estatais Federais & 0 & $0,0 \%$ & 0 & $0,0 \%$ & 1 & $1,4 \%$ & 1 & $0,8 \%$ \\
\hline Associações Religiosas & 1 & $3,6 \%$ & 0 & $0,0 \%$ & 0 & $0,0 \%$ & 1 & $0,8 \%$ \\
\hline $\begin{array}{l}\text { Servidores Públicos Inativos/ } \\
\text { Aposentados }\end{array}$ & 1 & $3,6 \%$ & 0 & $0,0 \%$ & 0 & $0,0 \%$ & 1 & $0,8 \%$ \\
\hline Outros $^{a}$ & 0 & $0,0 \%$ & 1 & $3,0 \%$ & 6 & $8,5 \%$ & 7 & $5,3 \%$ \\
\hline Total & 28 & $100,0 \%$ & 33 & $100 \%$ & 71 & $100 \%$ & 132 & $100 \%$ \\
\hline
\end{tabular}

Fonte: Elaborado pelos autores com base em dados obtidos dos Coredes.

a Em outros foram classificados aqueles ocupantes cujos segmentos ou entidades de origem não foram identificados.

Em alguns Coredes, os coordenadores dos Comudes passam a se constituir no grupo principal do Conselho de Representantes, o que vem contribuindo para reforçar o papel dos mesmos. Por outro lado, é necessário ter presente que os Comudes são espaços públicos locais cuja composição também se pauta nos princípios da 
pluralidade, porém, a coordenação dos Comudes é ocupada por um segmento dessa pluralidade, o que pode reforçar, em tese, um dos demais segmentos no âmbito do jogo de forças dos Coredes.

Também os servidores municipais (englobando aqui tanto os funcionários estatutários como os ocupantes de cargos em comissão, inclusive secretários municipais) ocupam 13,6\% do total dos cargos, especialmente os de tesoureiro e secretário. Em seguida, com $61 \%$ dos cargos, aparecem os movimentos sociais, que ocupam a presidência de três Coredes $(10,7 \%)$. Apesar disso, em diversas avaliações há recomendações no sentido de incentivar maior participação desse segmento nos Coredes, seja ocupando cargos nas diretorias executivas, seja por meio de uma presença mais ativa nos conselhos de representantes e nas assembleias.

Os estatutos dos Coredes, de um modo geral, definem mandatos de dois anos para os integrantes das diretorias executivas. Alguns Coredes permitem apenas uma reeleição para o mesmo cargo, mas a maioria permite reeleição sem limite de mandatos. Essa situação não tem sido apontada como um empecilho à atuação democrática e plural dos conselhos e dos segmentos que o integram. No entanto, essa norma pode levar a praticas de perpetuação no poder de determinado grupo. Como exemplo disso, pode ser mencionado o caso do Corede Centro-Sul, cujo presidente está no comando há mais de 10 anos. Em sua última eleição, já não era mais cidadão residente na área de abrangência do Corede, em razão de transferência de atividade profissional. Ainda assim, mesmo residindo e atuando profissionalmente fora da região, foi mais uma vez reeleito como presidente do Conselho. Em que pese o fato dos bons serviços voluntários prestados pelo referido cidadão ao movimento corediano, situações dessa ordem fragilizam o movimento. Em diversos momentos, os Coredes têm avaliado a necessidade de incorporar novas lideranças ao movimento, capacitando-as para assumir a coordenação do processo.

Classificam-se também como autônomas as assembleias públicas municipais e as assembleias regionais ampliadas, etapas do processo da Consulta Popular, coordenadas pelos Comudes e Coredes (Quadro 3). Percebem-se aí dinâmicas ainda muito diferentes nos municípios. Em 2009, por exemplo, nos municípios do Corede Noroeste Colonial, nas assembleias públicas municipais foram registrados os resultados constantes da Tabela 2. Em alguns municípios, a participação parece ter ficado restrita aos membros do próprio Comude, enquanto outros evidenciam um processo de participação mais aberto. Comparando-se o número de eleitores desses municípios, a participação nessa fase do processo variou de $0,5 \%$ a $6 \%$ dos eleitores.

Por outro lado, coordenações de Comudes argumentam que existe um trabalho preparatório anterior às assembleias municipais, com prazos para encaminhamento, por parte de entidades e/ou segmentos sociais, de projetos a serem submetidos à avaliação da assembleia. Por esse motivo, alegam que a participação pode ser menor numericamente, porém, mais qualitativa, com a presença de representantes de setores e entidades que já discutiram projetos em outros espaços.

Nas assembleias regionais ampliadas, os delegados eleitos nas assembleias públicas municipais passam a atuar juntamente com os membros das assembleias gerais regionais dos Coredes, com vistas à definição dos projetos que integrarão a cédula de votação da Consulta Popular.

Na prática, percebe-se que os Coredes não aproveitam o potencial dessa dinâmica de eleição de delegados, cuja única função tópica se restringe à mencionada anteriormente. Os Coredes poderiam integrar esses delegados no movimento corediano, aproveitando-os e qualificando-os como novas lideranças, tanto para qualificar o processo de monitoramento da execução dos projetos eleitos na Consulta, como para participar da discussão e promoção do desenvolvimento local e regional. 
Tabela 2

\section{Participantes das Assembleias Públicas Municipais no Corede Noroeste Colonial em 2009}

\begin{tabular}{|l|c|c|}
\hline \multicolumn{3}{|c|}{ Assembleias Públicas Municipais } \\
\hline Município & Participantes & $\begin{array}{c}\text { Delegados } \\
\text { eleitos }\end{array}$ \\
\hline Bozano & 31 & 1 \\
\hline Ajuricaba & 233 & 5 \\
\hline Nova Ramada & 62 & 2 \\
\hline Coronel Barros & 105 & 3 \\
\hline Augusto Pestana & 214 & 5 \\
\hline Condor & 40 & 1 \\
\hline Pejuçara & 12 & 1 \\
\hline ljuí & 204 & 5 \\
\hline Panambi & 226 & 5 \\
\hline Joia & 164 & 4 \\
\hline Catuípe & 65 & 2 \\
\hline Total & 1.356 & 34 \\
\hline
\end{tabular}

Fonte: elaborado pelos autores com base nas Atas das Assembleias.

Além disso, as assembleias regionais ampliadas poderiam eleger um ou mais representantes entre os delegados municipais, para constituir um colegiado de âmbito estadual, que poderia integrar a Comissão Estadual da Consulta Popular, hoje uma comissão paritária.

No que se refere à natureza dos espaços e ao caráter das deliberações, desde a emergência dos Coredes, os cidadãos e segmentos da sociedade que assumiram a bandeira do movimento corediano e se empenharam na sua construção tinham como objetivo motivador a ideia de que as sociedades regionais possuíam capacidade para pensar seu desenvolvimento, propor as ações necessárias para viabilizá-lo e que o Estado (nas diferentes esferas) teria o dever de implementar ou de prover os recursos necessários para sua concretização. Na realidade, persiste o confronto de diferentes concepções dos espaços públicos e seu papel na esfera pública. De um lado, o entendimento da esfera pública como a geradora das influências do mundo da vida que afetam as decisões do sistema político e, de outro, o entendimento da existência de uma esfera 
pública fortalecida por meio de mecanismos institucionais para que as decisões aí tomadas vinculem o sistema político, isto é, garantam que as deliberações do mundo da vida efetivamente sejam implementadas pelo mundo do sistema. De acordo com Allebrandt (2010), pela análise da trajetória dos Coredes, verifica-se que, em grande parte, isso continua sendo um ideal a perseguir, apesar dos inúmeros avanços obtidos na dinâmica de luta dessas duas décadas.

No Quadro 4, apresentam-se diversos processos e instâncias dos espaços públicos vinculados à dinâmica dos Coredes, classificados no grupo de espaços/processos consultivos ou deliberativos. Também se descrevem os processos considerados vinculantes e não vinculantes.

Os Coredes sempre consideraram elemento crucial à promoção do desenvolvimento a elaboração dos Planos Plurianuais do estado. Instrumento de planejamento de médio prazo, o PPA é elaborado sempre no primeiro ano de gestão dos governos e sua abrangência temporal é de quatro anos, com vigência do segundo ano de uma gestão até o final do primeiro ano da gestão seguinte.

Analisando as diferentes dinâmicas desenvolvidas pelos diversos governos nestes últimos vinte anos em relação ao planejamento de médio prazo, verifica-se que a relação estabelecida com os Coredes foi, no máximo, de parceria. De um modo geral, os governos utilizaram a leitura da realidade regional elaborada pelos Coredes, fortalecendo, assim, o diagnóstico técnico-político necessário ao planejamento. No entanto, entende-se que os processos periodicamente construídos pelos Coredes, seja nas suas avaliações anuais, seja na elaboração dos documentos denominados Pró-RS, ou mesmo nas propostas especificamente produzidas e elaboradas para subsidiar os Planos Plurianuais, inserem-se em praticas de democracia deliberativa.

Da mesma forma, em sentido estrito, as decisões tomadas em diferentes instâncias sobre o Plano Plurianual não obrigam o Executivo a incluir as decisões na proposta e ser encaminhada ao Legislativo. Também o Poder Legislativo, mesmo no caso da realização de audiências públicas de caráter regional para debater as propostas de planejamento ou orçamentárias, não está sujeito a incorporar as demandas defendidas pelas sociedades regionais nesses espaços.

Quadro 4

\section{O movimento corediano: natureza dos espaços e caráter das deliberações}

\begin{tabular}{|c|c|c|}
\hline Aspectos & Categorias & Espaços/Processos \\
\hline \multirow{8}{*}{$\begin{array}{l}\text { Natureza dos } \\
\text { espaços e } \\
\text { caráter das } \\
\text { deliberações }\end{array}$} & \multirow{3}{*}{ Consultivo } & Audiências Públicas do FDDR \\
\hline & & Audiências Públicas do PPA Estadual \\
\hline & & Plano Rumos-RS 2015 \\
\hline & \multirow{4}{*}{ Deliberativo } & Comissão Estadual da CP \\
\hline & & Assembleias Públicas Municipais da CP \\
\hline & & Assembleias Regionais Ampliadas da CP \\
\hline & & Assembleias Gerais dos Comudes, Coredes e Fórum dos Coredes. \\
\hline & Vinculante & $\begin{array}{l}\mathrm{CP} \text { - projetos escolhidos pelo voto popular passam a integrar a } \\
\text { proposta orçamentária do Estado - portanto, a CP vincula o governo } \\
\text { no âmbito do Executivo. }\end{array}$ \\
\hline
\end{tabular}




\begin{tabular}{|l|l|l|}
\hline Não vinculante & $\begin{array}{l}\text { Processo de participação na elaboração do PPA - Coredes e } \\
\text { Comudes envolvem-se e apresentam projetos estruturantes. } \\
\text { Governo avalia e incorpora ou não na proposta que encaminha ao } \\
\text { Legislativo. } \\
\text { No âmbito do FDDR repete-se a dinâmica. }\end{array}$ \\
\hline
\end{tabular}

Fonte: Allebrandt (2010, p. 217).

No caso da Consulta Popular, por força da própria Lei Estadual, os projetos/ações escolhidos pelo voto popular integram automaticamente os projetos das leis orçamentárias anuais. O Legislativo, ainda que pudesse modificar ou não aprovar tais demandas, dificilmente tomaria essa posição, pelas repercussões políticas consequentes.

Dessa forma, as manifestações da cidadania em processos de discussão e problematização nos espaços públicos são ouvidas pelo sistema político e, às vezes, transformam-se em decisões efetivas. Em alguns casos, as decisões tomadas nos espaços públicos possuem caráter vinculante, cabendo aos agentes políticos, à máquina burocrática, implementar as ações decididas no âmbito destes espaços.

No Quadro 5, reúnem-se informações a respeito da autonomia dos Coredes. Pode-se afirmar que o movimento corediano tem na autonomia um de seus princípios basilares. Na Declaração de Princípios adotada desde 1997 pelos Coredes, o segundo princípio defende a autonomia do movimento em relação às diferentes instâncias governamentais, às correntes político-partidárias ou a quaisquer outras organizações.

Sua postura de independência ao longo de sua trajetória, se em vários momentos colocou em risco sua existência, talvez tenha sido a principal força que permitiu seu reconhecimento pelos diversos governos.

Os Coredes não possuem infraestrutura própria. Por isso, dependem do apoio de outras instituições. Em termos de apoio institucional, por exemplo, os Coredes estão fortemente respaldados pelas instituições de ensino superior que atuam nas diferentes regiões, especialmente as universidades, centros universitários e faculdades de caráter comunitário, bem como unidades da universidade estadual e das universidades federais.

A Tabela 3 reúne as respostas dadas pelos Coredes a quesito que solicitava informação, por ordem de importância, sobre as entidades que lhes davam apoio institucional. As IES são a principal instituição de apoio a quatorze Coredes, sendo citadas em outros nove como apoiadoras importantes. O apoio das IES traduz-se na cessão de pessoal técnico de apoio (secretário executivo ou equivalente), em espaço físico para sediar os conselhos, em equipamentos básicos (computadores, móveis e utensílios) e materiais de consumo, além da logística de comunicação (internet, telefone, etc.). 


\section{Quadro 5}

\section{O movimento corediano e a autonomia dos espaços públicos de interação}

\begin{tabular}{|c|l|l|}
\hline Aspectos & \multicolumn{1}{|c|}{ Categorias } & \multicolumn{1}{c|}{ Espaços/Processos } \\
\hline \multirow{4}{*}{ Autonomia } & Financeira & $\begin{array}{l}\text { Coredes recebem algum recurso do estado para despesas de } \\
\text { manutenção. } \\
\text { Alguns Coredes viabilizam outros apoios de caráter mais regional. }\end{array}$ \\
\cline { 2 - 4 } & Administrativa & $\begin{array}{l}\text { Coredes dependem de parcerias com outras instituições } \\
\text { (universidades, prefeituras, Comudes, etc.). }\end{array}$ \\
\cline { 2 - 4 } & Infraestrutura/logística & $\begin{array}{l}\text { Coredes dependem de parcerias com outras instituições } \\
\text { (universidades, prefeituras, etc.). }\end{array}$ \\
\cline { 2 - 4 } & $\begin{array}{l}\text { Possibilidades de exercer } \\
\text { a própria vontade - } \\
\text { independência }\end{array}$ & $\begin{array}{l}\text { A atuação do movimento corediano tem se pautado pela } \\
\text { independência, cuja base está em sua declaração de princípios. }\end{array}$ \\
\hline
\end{tabular}

Fonte: Allebrandt (2010, p. 218).

Os Comudes também são citados por quinze Coredes como instituições de apoio à sua atuação. Este dado é importante, considerando que os Comudes, de criação mais recente, têm sido considerados espaços ineficientes e de pouca importância ao processo de promoção do desenvolvimento e da cidadania. A confirmação de mais da metade dos Coredes demonstra que está havendo avanços no fortalecimento da relação Coredes/Comudes como rede local/regional necessária ao processo.

A presença das associações de municípios é uma evidência de progressos no relacionamento dos Coredes com outros mecanismos de organização das sociedades regionais. Muitas regiões dos Coredes possuem a mesma abrangência territorial das associações de municípios, o que permite uma sinergia na busca de metas comuns de atuação. Algumas destas associações, inclusive, estão repassando auxílio financeiro para a manutenção dos Coredes. Em algumas regiões, a secretaria executiva do conselho funciona no mesmo espaço físico da associação de municípios, dividindo, portanto, a infraestrutura logística.

Os Coredes recebem o repasse de um valor mensal do estado, com base na legislação que os formalizou em 1994 e com base em critérios definidos pelo Fórum dos Coredes. Este valor é insuficiente para a manutenção dos conselhos, mas é considerado importante para o custeio de despesas de deslocamento dos dirigentes, telefone, material de consumo e outros serviços de terceiros. Os Coredes prestam contas anualmente dos recursos aplicados e devolvem o recurso eventualmente não utilizado.

No caso específico do Fórum dos Coredes, este deixou, no entanto, de receber o apoio financeiro do estado a partir de 2007, devido a parecer técnico da Contadoria e Auditoria Geral do Estado (CAGE), que entendeu que o Fórum, por não estar institucionalizado em lei, como no caso dos Coredes, não poderia receber repasse de recursos do estado. Esta situação perdurou por quatro anos. No final do governo Yeda, finalmente a Assembleia Legislativa aprovou a Lei 13.595 (de 30 de dezembro de 2010), dispondo sobre a institucionalização, a estruturação e o funcionamento do Fórum dos Coredes. 
Tabela 3

\section{Apoio institucional recebido pelos Coredes}

\begin{tabular}{|l|c|c|c|c|}
\hline \multirow{2}{*}{ Entidades que dão apoio } & \multicolumn{4}{|c|}{ Número de Coredes (por ordem de importância } \\
& \multicolumn{4}{|c|}{ das entidades) } \\
\cline { 2 - 6 } & Primeiro & Segundo & Terceiro & Quarto \\
\hline Universidades/IES & 14 & 4 & 2 & 2 \\
\hline Comudes & 1 & 5 & 7 & 2 \\
\hline Associações de Municípios & 3 & 7 & 2 & 5 \\
\hline Prefeituras Municipais & 5 & 5 & 9 & 2 \\
\hline $\begin{array}{l}\text { Outras entidades (órgãos estaduais ou } \\
\text { federais, sindicatos etc.) }\end{array}$ & 3 & 3 & 3 & 6 \\
\hline Não respondeu/Outros & 1 & 3 & 3 & 10 \\
\hline Não devolveu questionário & 1 & 1 & 1 & 1 \\
\hline Total & 28 & 28 & 28 & 28 \\
\hline
\end{tabular}

Fonte: elaborado pelos autores com base nos questionários.

Além desta verba de manutenção, a partir de 2003, os conselhos também recebem recurso específico repassado pelo Estado para o custeio do processo anual da Consulta Popular, cuja prestação de contas específica deve ser realizada após a conclusão do processo da Consulta. Além desses recursos, diversos Coredes estabelecem parcerias com os municípios ou com as Associações de Municípios, e seis conselhos informam o recebimento regular de repasse de recursos para sua manutenção.

O Quadro 6 retrata o movimento corediano em termos de pluralismo e igualdade participativa. A forma de escolha dos representantes, de um modo geral, é feita por meio da indicação das entidades que integram as instâncias dos Coredes. A cada dois anos, os conselhos solicitam às entidades e segmentos que compõem a Assembleia Geral a indicação formal dos representantes titulares e suplentes. Fica a critério de cada segmento a forma de efetuar as indicações. Este é um aspecto que merece maior atenção por parte dos Coredes, uma vez que a implantação de mecanismos mais publicizados e transparentes pode fortalecer a atuação dos Coredes nas suas regiões e ampliar a presença dos setores mais excluídos da sociedade. A utilização de editais de convocação para processos de indicação de representantes e a realização de fórum específico para que os segmentos possam discutir a indicação de candidatos para ocupar vagas na assembleia podem ser algumas formas de melhorar o funcionamento dos Coredes.

A avaliação participativa, no âmbito do Fórum dos Coredes, é um dos pontos positivos da atuação dos conselhos nestes vinte anos. A realização de encontros anuais de avaliação e planejamento é, certamente, um dos aspectos importantes na trajetória dos Coredes e, seguramente, um dos responsáveis pela sua continuidade como movimento da sociedade gaúcha.

A prática da edição e publicação das Cartas desses encontros, com a síntese do processo de avaliação e a sistematização das diretrizes e estratégias de atuação para o ano em curso, é fundamental nesta dinâmica. Os 
encontros são abertos à participação de qualquer cidadão, entretanto, mais uma vez, a presença principal é, além dos integrantes do Fórum e das diretorias dos Coredes, de representantes de Comudes e administrações municipais. Percebe-se aí a necessidade de dar maior capilaridade, ampliando esse processo de avaliação para o âmbito territorial regional e municipal. Os encontros anuais dos Coredes poderiam ser precedidos por encontros regionais, envolvendo não apenas os conselhos de representantes dos Coredes, mas todos os segmentos que compõem as assembleias regionais. Esta foi uma das constatações feitas no Primeiro Encontro Estadual dos Comudes, em 2007, que sugeriu a realização de encontros anuais de Comudes na região de cada Corede, além dos encontros anuais de avaliação dos Coredes e dos Comudes.

Quadro 6

O movimento corediano: pluralismo e igualdade participativa dos espaços públicos de interação

\begin{tabular}{|c|c|c|c|}
\hline Aspectos & & Categorias & Espaços/Processos \\
\hline \multirow{5}{*}{$\begin{array}{l}\text { Igualdade } \\
\text { participativa }\end{array}$} & \multicolumn{2}{|c|}{$\begin{array}{l}\text { Forma de escolha dos } \\
\text { representantes }\end{array}$} & $\begin{array}{l}\text { De modo geral, indicação pelas entidades que compõem as } \\
\text { instâncias dos conselhos. } \\
\text { O Fórum dos Conselhos escolhe em assembleia os } \\
\text { representantes em diferentes instâncias junto ao Poder } \\
\text { Executivo e Legislativo Estadual. }\end{array}$ \\
\hline & \multicolumn{2}{|c|}{ Avaliação participativa } & $\begin{array}{l}\text { Encontro Anual de Avaliação e Planejamento do Fórum dos } \\
\text { Coredes. }\end{array}$ \\
\hline & \multicolumn{2}{|c|}{$\begin{array}{l}\text { Canais de divulgação e } \\
\text { qualidade da informação }\end{array}$} & $\begin{array}{l}\text { Correio eletrônico, jornais e rádio são os canais mais } \\
\text { utilizados. }\end{array}$ \\
\hline & \multirow{2}{*}{$\begin{array}{l}\text { Prática } \\
\text { demo- } \\
\text { crática }\end{array}$} & $\begin{array}{l}\text { Voto universal } \\
\text { voluntário dos } \\
\text { participantes }\end{array}$ & Consulta Popular. \\
\hline & & $\begin{array}{l}\text { Voto universal dos } \\
\text { representantes }\end{array}$ & Fórum, assembleias, conselhos de representantes. \\
\hline
\end{tabular}

Fonte: Allebrandt (2010, p. 222).

No que se refere aos canais de difusão utilizados pelos Coredes para viabilizar a publicização de suas ações e garantir o acesso à informação por parte dos participantes das instâncias e processos desenvolvidos, o correio eletrônico é o meio mais utilizado. Neste aspecto, existe uma boa organização estabelecida para o fluxo de informações. O Fórum dos Coredes, por meio de sua Secretaria Executiva, repassa as informações aos integrantes das diretorias dos 28 Coredes, cujos endereços eletrônicos estão cadastrados. Tudo circula nesta rede: convocações, convites, temas em discussão, textos básicos para serem discutidos e apreciados nas assembleias do Fórum, demandas de órgãos do estado, da AL, de outras entidades (Uvergs, AGM, Famurs, Comitês de Bacias Hidrográficas, etc.) são permanentemente veiculadas por este canal. Os Coredes, por sua 
vez, mantêm suas redes de endereços eletrônicos dos participantes de seus conselhos de representantes e assembleias regionais e também dos Comudes.

A Tabela 4 reúne as informações a respeito dos canais de divulgação e difusão para as informações utilizados pelos Coredes.

Tabela 4

\section{Canais de difusão e divulgação mais utilizados pelos Coredes}

\begin{tabular}{|l|c|c|c|c|c|}
\hline \multirow{2}{*}{ Canais de difusão } & \multicolumn{3}{|c|}{$\begin{array}{c}\text { Número de Coredes (por ordem de } \\
\text { importância dos canais) }\end{array}$} & $\begin{array}{c}\text { Coredes que } \\
\text { citaram sem } \\
\text { ordenar }\end{array}$ \\
\cline { 2 - 6 } & Primeiro & Segundo & Terceiro & Quarto & \\
\hline Correio eletrônico (e-mail) & 18 & 1 & 2 & - & 5 \\
\hline Jornais regionais & 1 & 10 & 9 & - & 5 \\
\hline Emissoras de rádio da região & 1 & 8 & 7 & 3 & 4 \\
\hline Portal dos Coredes na Internet & - & 1 & 2 & 2 & - \\
\hline Telefone, Correio & - & - & - & 3 & - \\
\hline $\begin{array}{l}\text { Outros (TV, boletim impresso e eletrônico, } \\
\text { reuniões e assembleias) }\end{array}$ & 2 & 1 & - & 2 & 7 \\
\hline
\end{tabular}

Fonte: Elaborado pelos autores com base nos questionários.

Quanto ao tipo de informação veiculada entre os participantes dos Coredes, conforme se verifica na Tabela 5, informações de caráter geral sobre o desenvolvimento da região foram mais lembradas pelos Coredes, juntamente com as informações de caráter mais operacional sobre o processo da Consulta Popular realizada anualmente e sobre o andamento do processo de execução dos projetos escolhidos pelas regiões.

Além do correio eletrônico, o jornal e o rádio são os canais mais utilizados. Chama atenção a baixa utilização do Portal dos Coredes (http://www.nidus.org.br/coredesrs/sitemgr/sitemgr-site/), disponibilizado para a divulgação de informações pelos Coredes. Destes, cada um possui login e senha de acesso para disponibilizar as informações de sua região. Mesmo o Fórum dos Coredes praticamente não utiliza esse canal, criado especificamente com o objetivo de viabilizar maior interatividade entre os 28 Coredes e o Fórum, além de potencialmente ser um canal importante para o processo de transparência e publicização das ações dos conselhos.

No que se refere à consulta, é importante lembrar que o governo do estado mantém um portal específico (http://www.consultapopular.rs.gov.br) com as informações sobre os resultados das votações de todas as consultas realizadas desde 2003, inclusive sobre os projetos eleitos, além de permitir o acompanhamento da execução orçamentária dos projetos incluídos no Orçamento do Estado. 
Tabela 5

Tipo de informação que circula entre os participantes dos Coredes

\begin{tabular}{|l|c|c|c|c|}
\hline \multicolumn{1}{|c|}{ Tipo de informação } & \multicolumn{3}{c|}{$\begin{array}{c}\text { Número de Coredes (por ordem de } \\
\text { importância dos canais) }\end{array}$} \\
\cline { 2 - 5 } & Primeiro & Segundo & Terceiro & Quarto \\
\hline $\begin{array}{l}\text { Informações de caráter geral sobre o desenvolvimento } \\
\text { da região para manter os participantes informados }\end{array}$ & 8 & 1 & 10 & - \\
\hline $\begin{array}{l}\text { Informações sobre a Consulta Popular, repassadas pelo } \\
\text { Fórum e pelo Governo do Estado }\end{array}$ & 7 & 10 & 3 & 1 \\
\hline $\begin{array}{l}\text { Informações específicas relacionadas aos temas em } \\
\text { pauta para as reuniões do Corede, com vistas à } \\
\text { deliberação }\end{array}$ & 6 & 9 & 5 & \\
\hline $\begin{array}{l}\text { Diagnósticos e estudos setoriais produzidos pelos } \\
\text { diferentes órgãos e entidades que atuam na região }\end{array}$ & - & - & 2 & 11 \\
\hline
\end{tabular}

Fonte: Elaborado pelos autores com base nos questionários.

Além destas informações, os Coredes citaram também as relativas ao processo de luta organizada contra a renovação da concessão das praças de pedágio gaúchas, movimento no qual os Coredes estão engajados há vários anos e que impediu, em 2009, a renovação antecipada dos contratos com as empresas concessionárias, conforme projeto encaminhado pelo Executivo à Assembleia Legislativa.

\section{Considerações Finais}

O retorno à democracia no Brasil, durante a década de 80 do século passado, no âmbito normativo, concretizou-se na Constituição Cidadã de 1988, que estabeleceu no país um modelo de democracia semidireta ou participativa. Ao longo destas duas últimas décadas, diferentes práticas foram desenvolvidas e diferentes arranjos institucionais vêm sendo experimentados em todo o território nacional. Conselhos gestores de políticas públicas e as experiências do orçamento participativo são os exemplos mais típicos deste período, surgidos tanto por processos de lutas de segmentos da sociedade quanto por vontade política de agentes públicos, especialmente no âmbito da esfera de poder municipal.

Mais raras são as experiências que procuraram transferir ao âmbito supramunicipal e estadual dinâmicas de inserção direta e participação da sociedade no processo de discussão e promoção do desenvolvimento e das decisões sobre as políticas públicas. Mais raras ainda, experiências de âmbito regional/estadual que sobreviveram a diferentes governos estaduais. Este é o caso dos Conselhos Regionais de Desenvolvimento implantados no Rio Grande do Sul no início da década de 1990 e que continuam atuando como espaço de interação entre a sociedade e o estado após seis diferentes governos. 
Neste estudo, buscou-se compreender em que medida os Coredes fortalecem o processo de construção da cidadania e a gestão do processo de desenvolvimento local e regional e se esses arranjos institucionais podem ser entendidos como espaços deliberativos que contribuem para o fortalecimento da democracia participativa e a prática da gestão social.

A democracia deliberativa é entendida como um modelo político decisório que tem como um de seus elementos centrais a participação da população na definição das políticas públicas, isto é, a participação da sociedade civil na regulação da vida coletiva constitui-se em pressuposto teórico-normativo. Pauta-se em relações dialógicas entre os participantes, que, articulando cooperação e conflito, permitem que a cidadania decida orientada por diversos princípios, em especial os da inclusão, do pluralismo, da igualdade participativa, da autonomia e da justiça social ou bem comum.

Com base nesse conceito ampliado de cidadania deliberativa, foram recuperados e analisados diferentes modelos de análise de experiências concretas e elaborada uma matriz de categorias que orientou o processo de análise desta pesquisa.

A análise evidenciou como os Coredes praticam o pluralismo, a igualdade participativa, como se desenvolvem os diversos processos deliberativos e decisórios, e como estão compostas as relações internas de poder das instâncias e espaços participativos.

Os processos deliberativos enfrentam dificuldades de operacionalização, relacionadas aos arranjos institucionais e às condições de inclusão e de condução do processo, ou quanto aos resultados possíveis.

Os Coredes sobreviveram a seis administrações estaduais coordenadas por diferentes partidos e coligações partidárias, mantendo sua independência e autonomia em relação a partidos políticos e ideologias programáticas dos governos. Mesmo assim, ao longo desses vinte anos de história, apresentam grandes dificuldades na sua manutenção.

Por muito tempo houve razoável ausência de compreensão do papel que cabe aos Coredes no processo político, devido à persistência de traços da democracia clientelista nas diferentes regiões do estado.

A partidarização das disputas para ocupar a coordenação de Coredes, em diversos momentos, dificultou, em algumas regiões, o processo de construção de identidade e de poder da sociedade civil. Este mesmo fator levou à fragmentação de alguns Coredes e, por sua vez, à criação de novos conselhos. Há necessidade de se retomarem as discussões sobre os critérios básicos para a criação de novos Coredes, pois se corre o risco de balcanização do processo de identidades regionais.

Da mesma forma, há necessidade de superar as diferenças de infraestrutura e recursos entre os conselhos, a persistência de alto grau de desmobilização e de desconhecimento ou falta de compreensão do papel que cabe aos Coredes no processo político por parte de vários segmentos da sociedade, a inexistência de um programa permanente de qualificação dos conselheiros e conselhos no âmbito municipal e regional e fortalecer a inserção dos coredianos nos diferentes espaços de governança.

Desafio dos Coredes é não se afastar do seu papel estratégico de articular a promoção do desenvolvimento e se concentrar prioritariamente na tarefa de coordenação do processo das consultas populares e dinâmicas similares em diferentes governos estaduais. Esta preocupação é seguidamente apontada pelos próprios Coredes em seus processos de avaliação. $\mathrm{O}$ desenho da atual $\mathrm{CP}$ é, em grande parte, construção do movimento corediano, assumido por diferentes governos. O risco, como ocorre em algumas regiões, é que o Corede, e especialmente os Comudes, restrinjam sua existência à realização da CP. Se existe o dever legal de participar da organização e implementação desses processos, isso deve ser assumido sem que se abandone a formulação de diretrizes estratégicas de desenvolvimento para as regiões. O recente esforço de elaboração 
dos Planos Regionais de Desenvolvimento pode contribuir nesse sentido, desde que os Coredes se empenhem para que a definição dos projetos e a escolha da população estejam em sintonia com os objetivos estratégicos presentes nesses planos. Além disso, os Coredes deveriam avançar no sentido de qualificar o processo de prestação de contas por parte do governo nas Audiências Públicas da $\mathrm{CP}$, analisando todo o orçamento do estado, bem como em relação ao montante disponibilizado para a $\mathrm{CP}$, hoje em menos de $0,5 \%$ do total do orçamento e aproximadamente $2,5 \%$ da despesa de capital.

Por outro lado, a prática de definição, por meio da escolha popular, de parte do orçamento público do estado, deve ser ampliada para processos similares no âmbito local. Os Coredes e Comudes podem ser mais propositivos em seus municípios, incentivando os governos municipais a tornarem o processo de alocação dos recursos públicos mais transparentes, adotando metodologias participativas como o orçamento participativo e as consultas populares.

A quase generalizada baixa participação de segmentos comunitários e populares, em especial dos menos organizados, que se imaginava seria rapidamente solucionada com a implantação dos Comudes e sua potencial presença capilar nas comunidades locais, permanece um problema a ser mais bem equacionado pelo movimento corediano.

A relação dos Coredes e Comudes com os poderes legislativos municipais não tem sido significativa. Os legislativos municipais, como se verificou no estudo de caso do Noroeste Colonial, participam formalmente das assembleias e/ou dos conselhos de representantes dos Comudes, da mesma forma que integram as instâncias formais dos Coredes. A participação, no entanto, é pouco efetiva. Caberia um esforço de aproximação por parte dos Coredes e Comudes como elementos da democracia participativa, da estrutura e dinâmica da democracia representativa. No âmbito estadual, o Fórum dos Coredes tem buscado esta integração, tanto que, nos últimos três anos, conseguiu apoio institucional em termos de infraestrutura administrativa e logística. A relação do Fórum e dos Coredes com o Parlamento dá-se especialmente pela atuação do Fórum Democrático de Desenvolvimento Regional (FDDR). No entanto, a relação com o parlamento gaúcho parece bastante condicionada à vontade da sua presidência. Como o mandato de presidente da Assembleia Legislativa é de apenas um ano, constitui-se um desafio permanente para o Fórum dos Coredes garantir continuidade e perenidade numa parceria entre o movimento e o parlamento.

A ênfase numa atuação mais articulada e integrada entre os Coredes e os Comudes merece mais atenção por parte do movimento. Os Comudes têm sido presas mais fáceis de aparelhamento partidário ou de governo, dificultando o cumprimento de sua função de promotor do desenvolvimento local e articulador da dinâmica de interação e controle social em que atuam os diferentes e diversos conselhos setoriais e programáticos que existem nos municípios. O envolvimento mais efetivo dos Comudes na dinâmica dos Coredes é uma estratégia que pode qualificar esse processo.

Outro aspecto para novos estudos diz respeito à articulação nacional dos Coredes. As diferentes escalas territoriais têm impacto no desenvolvimento regional e local. Deste modo, as articulações entre as escalas de poder regional e nacional significaram a inclusão de recursos no Plano Plurianual da União e o reconhecimento pelo governo federal do papel inovador dos conselhos no processo de gestão do desenvolvimento territorial. Por isso, a relação e integração dos Coredes com os Fóruns das Mesorregiões (Metade Sul e Grande Fronteira do Mercosul) e o papel dos Coredes na institucionalização das Mesorregiões como política pública de caráter nacional, iniciada no governo FHC e mantida e aperfeiçoada no governo Lula e no governo Dilma, precisam ser mais bem estudados e compreendidos.

A democracia é uma construção. Coredes e Comudes constituem-se uma nova forma de praticar a democracia. Representam processos de cidadania deliberativa, que vêm produzindo mudanças, ainda que lentamente, na perspectiva pública dos indivíduos, na cultura da sociedade civil, na postura e modo de agir 
da sociedade política e no modus operandi da máquina burocrática e dos governos. É, entretanto, um processo de mudança em longo prazo, para o qual é necessária uma prática contínua, não episódica e pontual. Trata-se de processo dialógico, que necessita ser construído e reconstruído permanentemente pelos participantes, para evitar o risco do controle corporativo, político ou administrativo por meio de cooptação e manipulação.

O formato institucional dos Coredes e dos Comudes, ao mesmo tempo em que resulta do processo deliberativo, provoca mudanças nos princípios democráticos. Estes arranjos institucionais, com suas regras, critérios, instâncias e espaços construídos pelos participantes assumem um determinado desenho que confere operacionalidade ao processo deliberativo, e, mais que isso, também modificam padrões políticos, econômicos e sociais, isto é, transformam o quadro mais amplo da cultura e das relações sociais.

\section{Referências}

ALLEBRANDT, S. L. A participação da sociedade na gestão pública. Ijuí: Ed. Unijuí, 2002.

Conselhos Municipais: potencialidades e limites para a efetividade e eficácia de um espaço público para a construção da cidadania interativa. In: ENANPAD, 27, 2003, Atibaia. Anais... Atibaia-SP: ANPAD, 2003. CD-ROM.

Conselhos distritais e a gestão do desenvolvimento local: relações de poder e participação na gestão pública local. In: SEMINÁRIO INTERNACIONAL SOBRE DESENVOLVIMENTO REGIONAL, 3, 2006, Santa Cruz do Sul. Anais... Santa Cruz do Sul: Edunisc, 2006. CD-ROM.

Conselhos distritais e a gestão do desenvolvimento local: relações de poder e participação na gestão pública. In: BAQUERO, M.; CREMONESE, D. (Org.). Desenvolvimento regional, democracia local e capital social. Ijuí: Ed. Unijuí, 2008. p. 173-210.

Cidadania e gestão do processo de desenvolvimento: um estudo sobre a atuação dos conselhos regionais e municipais de desenvolvimento do Rio Grande do Sul, de 1990 a 2009. 302 f. Tese (Doutorado em Desenvolvimento Regional) - Universidade de Santa Cruz do Sul, 2010.

AVRITZER, L. Teoria democrática, esfera pública e participação local. Sociologias, Porto Alegre, v. 1, n. 2, p.18-43. jul./dez. 1999.

BANDEIRA, P. S. Participação, Articulação de atores sociais e desenvolvimento regional. Texto para discussão do IPEA. Brasília, n. 630, fev. 1999.

Participação, Articulação de Atores Sociais e Desenvolvimento Regional. In.: BECKER, D. F.; BANDEIRA, P. S. (Org.). Desenvolvimento local-regional: determinantes e desafios contemporâneos. v. 1. Santa Cruz do Sul: EDUNISC, 2000. p. 23-128.

O capital social e a atuação dos Conselhos Regionais de Desenvolvimento do Rio Grande do Sul. 2003. 365 f. Tese (Doutorado em Ciência Política) - Programa de Pós-Graduação em Ciência Política, Universidade Federal do Rio Grande do Sul, Porto Alegre, 2003.

. Articulação de Atores Sociais, Capital Social e Desenvolvimento Regional: o caso dos Conselhos Regionais de Desenvolvimento do Rio Grande do Sul. In: SUPERINTENDÊNCIA DE ESTUDOS ECONÔMICOS E SOCIAIS DA BAHIA (Org.). Desigualdades Regionais. Salvador: SEI, 2004. p. 219-50. (Série Estudos e Pesquisas, n. 67).

BECKER, D. F. Coredes na trilha do aperfeiçoamento (entrevista). In: ALLEBRANDT, S. L. (Ed.) Espaços Públicos: visões e reflexões. Caderno Hora H Cidadania, Ijuí, Coomunica, 04 abr. 2003. p. 8. 
BIRKNER, W. M. K. Capital social em Santa Catarina: o caso dos Fóruns de Desenvolvimento Regional. Blumenau: Furb, 2006.

CARVALHO, J. et al. Conselhos municipais: sua contribuição para o desenvolvimento local. In: ENANPAD, 23. Anais... Foz do Iguaçu: ANPAD, 1999. CDROM.

COHN, A. Os governos municipais e as políticas sociais. In: SOARES, J. A.; CACCIA-BAVA, S. (Org.). Os desafios da gestão municipal democrática. São Paulo, Cortez, 1998. p. 143-192.

DECLARACIÓN DE MÁLAGA. Constitución del grupo de trabajo sobre democracia participativa e presupuestos participativos. Málaga, marzo 2007. Disponível em: 〈http://redfal.org>. Acesso em: 13 mai 2009.

DOWBOR, L. Governabilidade e descentralização. Artigos Online. São Paulo, 1994. Disponível em: <http://www.ppbr.com/ld/govport.shtml_. Acesso em: 19 set. 2001.

Da globalização ao poder local: a nova hierarquia dos espaços. Artigos Online. São Paulo, 1995. Disponível em: <http://dowbor.org/5espaco.asp>. Acesso em: 02 mai. 2007.

O poder local diante dos novos desafios globais. In.: FUNDAÇÃO PREFEITO FARIA LIMA. O município no século XXI: cenários e perspectivas. São Paulo: CEPAM, 1999. Disponível em: <http://www.cepam.sp.gov.br/v11/biblioteca/publicacoes_download.asp z. Acesso em: 23 abr. 2007.

FEDOZZI, L. Orçamento participativo: reflexões sobre a experiência de Porto Alegre. 2. ed. Porto Alegre: Tomo Editorial; Rio de Janeiro, FASE/IPPUR, 1999.

Editorial, 2000

O poder da aldeia: gênese e história do orçamento participativo de Porto Alegre. Porto Alegre: Tomo

FERNANDES, J. O arquiteto de um caminho direcionado ao desenvolvimento. In: ROTH, J. L. de O. (Ed.). Sala 406, onde tudo começou - Coredes: a participação popular. Santa Maria: Casa Editorial, 2005. p. 25-27.

FISCHER, T. Gestão contemporânea, cidades estratégicas: aprendendo com fragmentos e reconfigurações do local. In: 13-23. (Org.). Gestão contemporânea, cidades estratégicas e organizações locais. Rio de Janeiro: Ed. FGV, 1996. p.

Poderes locais, desenvolvimento e gestão: introdução a uma agenda. In: FISCHER, Tânia (Org.). Gestão do desenvolvimento e poderes locais: marcos teóricos e avaliação. Salvador: Casa da Qualidade, 2002. p. 12-32.

FRANTZ, W. Um processo de educação política na participação do debate sobre desenvolvimento regional: a experiência de organização dos Conselhos Regionais de Desenvolvimento do Estado do Rio Grande do Sul. Redes, Santa Cruz do Sul, v. 9, n. 2, p. 7-29, mai./ago. 2004.

GOHN, M. da G. M. Conselhos gestores e participação sociopolítica. São Paulo: Cortez Editora, 2001.

GOMES, J. M. Política e democracia em tempos de globalização. Petrópolis: Vozes; Buenos Aires: Clacso; Rio de Janeiro: LPP, 2000.

JORBA, L.; MARTÍ, J.; PARÉS, M. La qualitat em la participación: orientacions per a l'avaluació participada. Finestra Oberta, n. 51, Barcelona, 2007.

LÜCHMANN, L. H. H. A democracia delibrativa: sociedade civil, esfera pública e institucionalidade. Cadernos de Pesquisa do PPGSP/UFSC, n. 33, p. 1-44, nov. 2002a. 
Possibilidades e limites da democracia deliberativa: a experiência do orçamento participativo de Porto Alegre. 2002. 215 f. Tese (Doutorado em Ciências Sociais) - Departamento de Ciência Política do Instituto de Filosofia e Ciências Humanas da Universidade Estadual de Campinas, Campinas, São Paulo, 2002b.

A representação no interior das experiências de participação. Lua Nova, São Paulo, n. 70, p. 139-170, 2007.

MAPAS-FEE. Disponível em: <http://mapas.fee.tche.br/wp-content/uploads/2009/08/coredes_rs_2008.png>. Acesso em: 13 mar. 2010.

NYGAARD, P. D. As regionalizações e o planejamento estadual - uma discussão sobre as dificuldades e possibilidades de um ajustamento. Ensaios FEE, Porto Alegre, v. 11, n. 1, p. 184-197, 1990.

PARÉS, M.; CASTELLÀ, C. Criteris, metodolies i reflexions entorn l'avaluació de la participación ciutadana. 2008. Mimeo.

; JORBA, L. Alguns criteris i recomanacions per millorar la qualitat dels processos participatius. Innovación democràtica, Barcelona, n. 2, p. 29-40, fev. 2007.

RÜCKERT, A. A. Reforma do Estado e tendências de reestruturação territorial. Cenários contemporâneos no Rio Grande do Sul. 2002. Tese (Doutorado em Geografia Humana) - Programa de Pós-Graduação em Geografia, Universidade de São Paulo, São Paulo, 2002.

SIEDENBERG, D. R. Sozioökonomische Disparitäten und regionale Entwicklungpolitik in Rio Grande do Sul. Eine Analyse über Handlungsspielraum, Auswirkungen und Perspektiven endogener Regionalentwicklungsstrategien in Südbrasilien. 2000. Tese (Geographisches Institut der Universität Tübigen) - Tübingen/Alemanha, 2000.

TENÓRIO, F. G. (Org.) Cidadania e desenvolvimento local. Rio de Janeiro: FGV; Ijuí: Ed. Unijuí, 2007.

; VILLELA, L. E.; DIAS, A. F. et al. Critérios para a avaliação de processos decisórios participativos deliberativos na implementação de popolíticas públicas. In: EnAPG, 3., Salvador, 2008. Anais... Salvador: EnAPG, 2008.

Metodologia de construção dos critérios para a avaliação de processos decisórios participativos deliberativos na implementação de políticas públicas. In: RIGO, A. S.; SILVA JR., J. T.; SCHOMMER, P. C. et al. Gestão social e políticas públicas de desenvolvimento: ações, articulações e agenda. Recife: Univasf, 2010. p. 394-401.

THOMPSON, J. B. Idelologia e cultura moderna: teoria crítica na era dos meios de comunicação de massa. Petrópolis: Vozes, 1995.

VEIGA, J. E. da. Vicissitudes da governança cidadã: os conselhos regionais gaúchos (COREDE). RDE - Revista de Desenvolvimento Econômico, v. 8, n. 13, p. 19-27, jan. 2006a. Disponível em: <http://www.fea.usp.br/professores/zeeli/>. Acesso em: 15 jan. 2009.

Potencial de cooperação e articulação no desenvolvimento rural. Cadernos do CEAM, v. 5, n. 23, p. 221-278, jan. 2006b. Disponível em <http://www.fea.usp.br/professores/zeeli/>. Acesso em: 15 jan. 2009. 